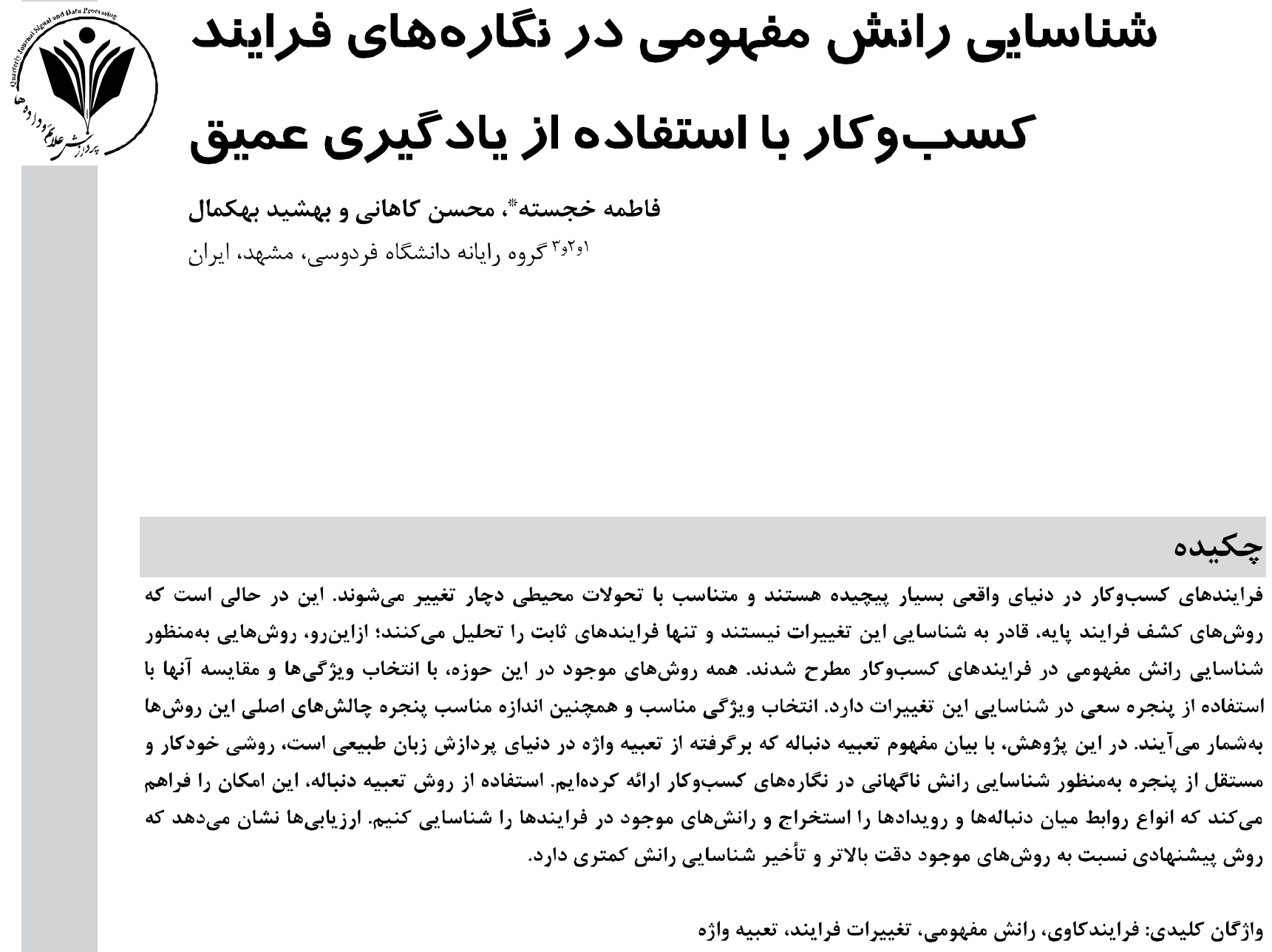

\title{
Concept drift detection in business process logs using deep learning
}

\author{
Fatemeh Khojasteh*, Mohsen Kahani \& Behshis Behkamal \\ Departeman Computer Engineering, Ferdowsi University of Mashhad, Mashhad, Iran
}

\begin{abstract}
Process mining provides a bridge between process modeling and analysis on the one hand and data mining on the other hand. Process mining aims at discovering, monitoring, and improving real processes by extracting knowledge from event logs. However, as most business processes change over time (e.g. the effects of new legislation, seasonal effects and etc.), traditional process mining techniques cannot capture such "second-order dynamics" and analyze these processes as if they are in steady-state. Such changes can significantly impact the performance of processes. Hence, for the process management, it is crucial that changes in processes be discovered and analyzed. Process change detection is also known as business process drift detection.

All the existing methods for process drift detection are dependent on the size of windows used for detecting changes. Identifying convenient features that characterize the relations between traces or events is another challenge in most methods. In this thesis, we propose an automated and window-independent approach for detecting sudden business process drifts by introducing the notion of trace embedding. Using trace embedding makes it possible to automatically extract all features from the relations between traces.

* Corresponding author

*نويسندة عهدهدار مكاتبات


We show that the proposed approach outperforms all the existing methods in respect of its significantly higher accuracy and lower detection delay.

Keywords: process mining, concept drifts, process changes, word embedding

روشهاى متنوعى را جهت شناسايى تغييرات فرايند ارائه

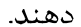

در سالهاى اخير روشهاى متعددى براى شناسايى

رانش مفهومى در نغارههاى كسبوكار مطرح شده است كه هركدام بر روى ديدگاه (ها) و رانشهاى مختلفى تمركز كردهاند. بيشتر روشهاى موجود نيازمند بـ رون استخراج

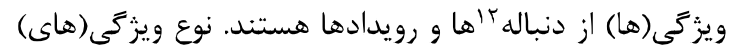

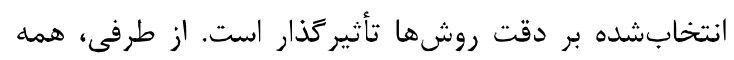
روشهاى موجود از دو رنجره متوالى استفاده كرده و مقادير

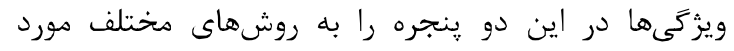
مقايسه قرار مىدهند. نتايج ارائهشده در اين روشها نشان نشان مىدهد كه دقت شناسايى رانشها بهشدت به نوع و اندازه ينجره استفادهشه وابسته است؛ بنابراين بهنظر مىرسد كه مىتوان با ارائه روشى مستقل از ينجره كه توانايى استخراج

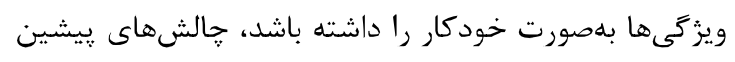
را برطرف كرد. ايده ييشنهادى بدينصورت است كه با توجه

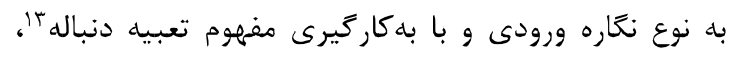
مىتوان دنبالههاى موجود در نغاره كسبوكار را به بردارهايى مدل كرد؛ بهطورى كه روابط ميان بردارها در فضاى بردارى، بيان

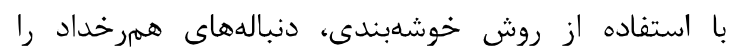

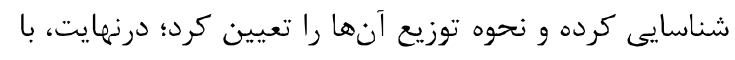
استفاده از تبديل فوريه و شناسايى تغييرات اصلى قادر خواهيم بود رانشها و مكان دقيق آنها را شناسايى كنيم.

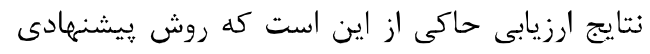

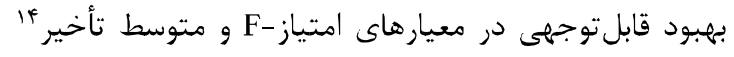
نسبت به ساير روشها ايجاد كرده است؛ بنابراين، نوآورىهاى اين يزروهش بلهصورت زير خلاصه مىشود:

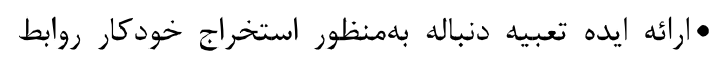

$$
\text { ميان دنبالهها و رويدادها }
$$

•حذف ينجره بdمنظور شناسايى رانشها و واستفاده از رونيان معيار شباهت دنبالهها

•استفاده از تبديل فوريه بهمنظور شناسايى مكان دقيق مانق رانش و كاهش متوسط تأخير

12 Trace

${ }^{13}$ Trace embedding

${ }^{14}$ Mean delay

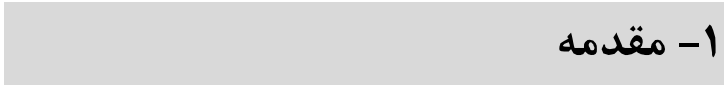

فرايندكاوى' يك زمينه يزوهشى بهنسبه جديد است كه با

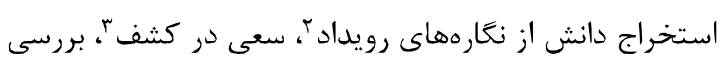

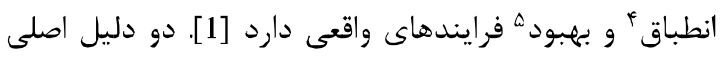
براى افزايش يزوهشها در حوزه فرايندكاوى وجود دارد. از بـوني يكسو، به كمك رويدادهاى ثبتشده در نكاره رويداد مئرتوان اطلاعات ارزشمندى درباره تاريخجه فرايندهاى سازمانى تدي بهدست آورد. از سوى ديخر، با توجه به فضاى رقابتى رئى كسبوكار و تغييرات محيطى، نياز به بهبود و ورشتيبانى از فرايندهاى كسبوكار اهميت بسيارى دارد.

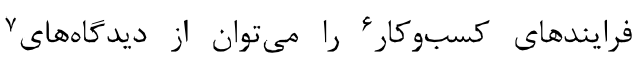

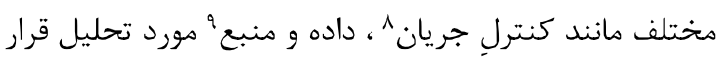

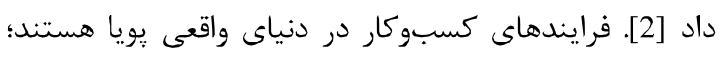

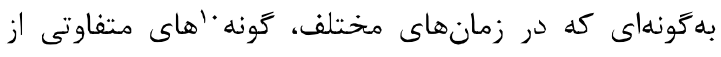
يك فرايند اجرا مىشود. وجود تغييرات بسيار در نرخ عرضه و تقاضا، تغييرات فصلى، وضع قوانين جديد، بلاياى طبيعى و غيره ازجمله وقايعى هستند كه سازمانها را مجبور مىسازد تا فرايندهاى خود را تغيير دهند. اين در حالى استى است كه

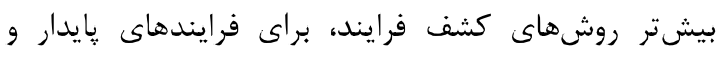

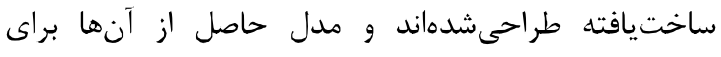

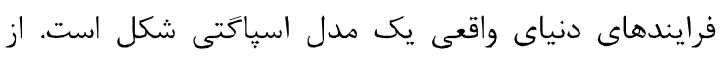
طرفى ديگر، سازمانها در تلاش هستند با سادهسازى

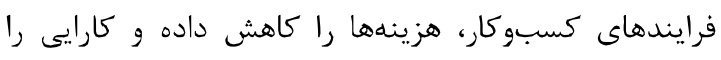

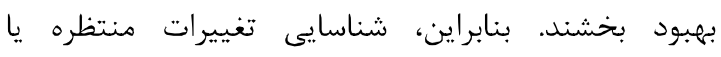
غيرمنتظره در رفتار فرايندها و تحليل آنها، اطلاعات

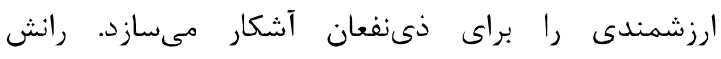
مفهومى "' زمانى رخ مى دهد كه فرايند در هنخام تحليل دجار تغيير شده باشد [1]. نياز به مديريت اين تغيتئيرات،

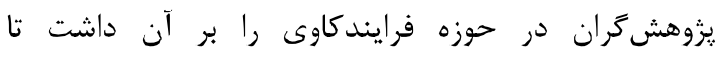

\footnotetext{
${ }^{1}$ Process mining

${ }^{2}$ Event $\log$

${ }^{3}$ Discovery

${ }^{4}$ Conformance checking

${ }^{5}$ Enhancement

${ }^{6}$ Business process

${ }^{7}$ Prespective

${ }^{8}$ Control-flow

${ }^{9}$ Resource

${ }^{10}$ Variant

${ }^{11}$ Concept drift
} 
هختلفى هستند. براى هر نمونه

(3) نشاندهنده مقدار صفت n براى رويداد e است [3). هر نمونه داراى يك صفت اجبارى مخصوص به نام دنباله است: رويدادها است، نغاره رويداد يك مجموعه از نمونههاى است،

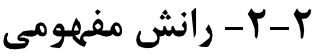

منظور از رانش مفهومى در يادَيرى ماشين و داده كاوى، ايجاد تغيير هيشبينىنشده در رابطه بين داده ورودى و متغير هدف در طول زمان است [4] يا بهعبارت ديكر هر تغيير در نحوه توزيع داده در طى زمان را رانش مفهومى رمى كويند.

علاوهبر حوزههاى يادكيرى ماشين و دادهكاوى، در سالهاى اخير شناسايى رانش مفهومى در حوزه فرايندكاوى

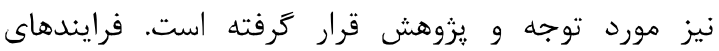
كسبوكار دنياى واقعى يويا هستند و در بازههاى زمانى

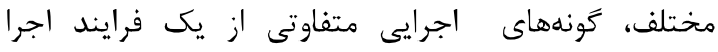
مىشوند. اين در حالى است كه روشهاى فرايندكاوى يايه،

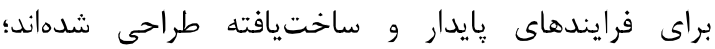
بنابراين، مدل حاصل از اين روشها براى فرايندهاى دنياى واقعى يك مدل اسياگتى شكل است. مدلهاى اسياگتى شكل، بسيار رييجيده هستند و به همين دليل توصيف دقيق و واضحى از فرايند اصلى در حال اجرا ارائه نمىدهند؛ بنابراين، فرض ثابت بودن فرايند در حين اجرا، يك فرض

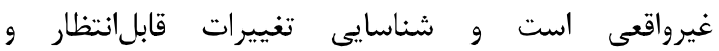
غيرقابلانتظار در رفتار فرايندها و تحليل آنها، اطلاعات ارزشمندى را براى ذىنفعان آشكار مىسازد. در [1] از يازده موضوع بهعنوان جالشهاى موجود در حوزه فرايندكاوى ياد شده كه جهارمين خالش مطرحشده در آن، شناسايى رانش مفهومى در فرايندهاى كسبوكار است و آن را به اين صورت تعريف مى كند: "رانش مفهومى زمانى رخ مئدهد كه فرايند در هنگَام

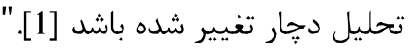

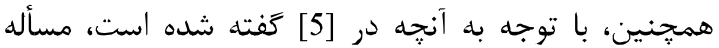
شناسايى رانش مفهومى در فرايندهاى كسبوكار از ديد آناه آمارى عبارت است از شناسايى نقطهاى از زمان كه ميان رفتار فرايند در قبل و بعد از اين نقطه، اختلاف قابلملاحظه آمارى وجود داشته باشد.
ادامه مقاله بدين صورت بخشبندى شده است. در بخش دوم، مرور كارهاى كذشته مطرح مىشود. در ابتداى موري اين بخش به بيان مفاهيم اوليه ״رداخته شده و سيس روشهاى موجود در شناسايى رانش فرايند بحث شده است. روش يِيشنهادى در بخش سوم بيان شده است. بخش جهرارم دربردارنده نتايج و ارزيابىهاى انجامشده بر روى برى نكارههاى

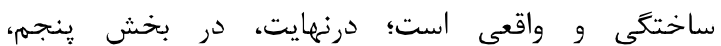
نتبجدَيرى و كارهاى آينده بيان مىشود.

\section{ץ- مرور كارهاى كذشته}

هدف از اين بخش، بيان مفاهيم اوليه در حوزه فرايندكاوى،

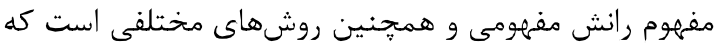
تاكنون در زمينه شناسايى رانش مفهومى در فرايندهاى كسبوكار ارائهشدهاند.

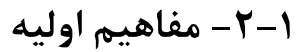
نقطه شروع براى فرايندكاوى، وجود يكى نحاره رويداد است. تمامى روشهاى فرايندكاوى بر اين فرض هستند كه امكان ثبت ترتيبى رويدادها به گونهاى كه هر رويداد به يك فعاليت و به يك نمونه(مورد) خاص اشاره كند، وجود دارد. بهعبارت ديگر، رويدادها به نمونههاى فرايند مرتبط و از طريق نام فعاليتها توصيف مىشوند. رويدادها در يك نمونه فرايند

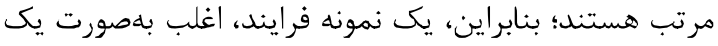

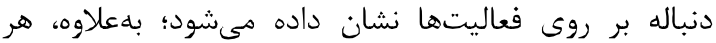
رويداد مىتواند صفاتى مانند منبع (شخص يا دستخاه)

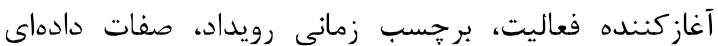

(مقدار يا نوع مشترى) داشته باشد [3]. (رويداد و صفت): فرض كنيد E مجموعهاى از رويداد'ها

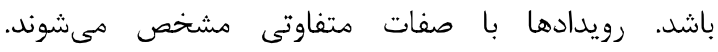
بهعنوانمثال، هر رويداد مىتواند يك برجسب زمانى، نام

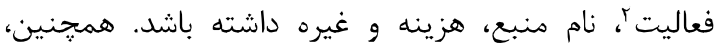
فرض كنيد AN مجموعداى از نام صفتهاى مختلف باشئ ميره براى هر رويداد مقدار صفت n براى رويداد e است. اگر رويداد e، صفتى با رون

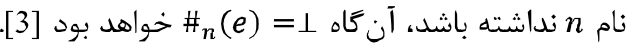
(نمونه، دنباله، نَّاره رويداد): فرض كنيد C مجموعهاى از نمونه ؟ها است. نمونهها نيز مانند رويدادها داراى صفات

\footnotetext{
${ }^{1}$ Event

${ }^{2}$ Activity

${ }^{3}$ Case
} 

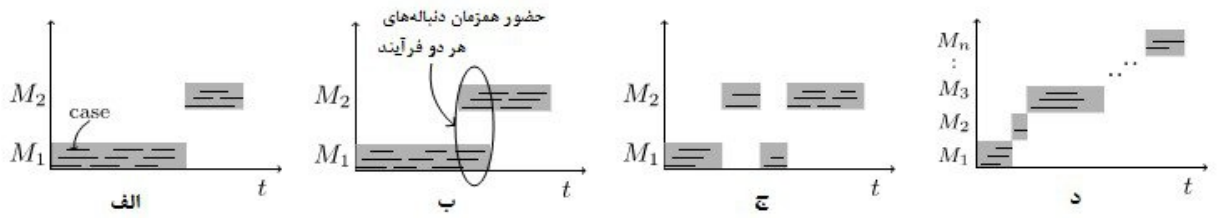

(شكل -1): انواع رانش. الف) رانش ناكَهانى، ب) رانش تدريجى، ج) رانش متناوب، د) رانش افزايشى.[5]

(Figure-1): Different types of drifts. (a) Sudden drift. (b) Gradual drift. (c) Recurring drift. (d) Incremental drift

وجود دارد. بهعنوانمثال، سازمانى را در نظر بخيرد كه إنهان

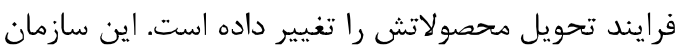

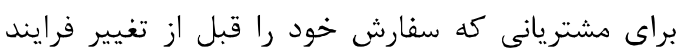

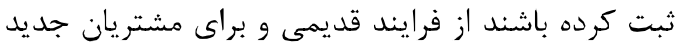
از فرايند جديد استفاده مى كند.

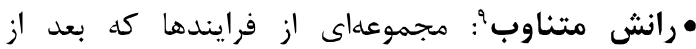
مدتزمانى مجدد ظاهر مىشوند. اين تغييرات ممكن فئن

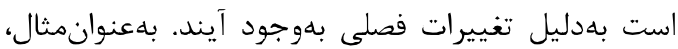
يك شركت مسافرتى از فرايندى متفاوت در ائهات

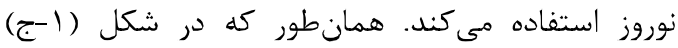
مشاهده مىشود فرايند جايكزين فرايند M M Mده است

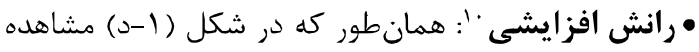
مىشود، فرايند

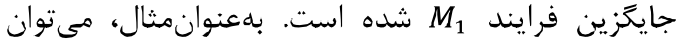

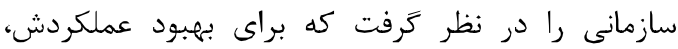
تغييرات كم اما افزايشى و بلندمدت را بر روى رئر فرايند

$$
\text { اوليه خود اعمال مى كند. }
$$

\section{r-r - r - روش هاى شناسايى رانش فرايند}

بيشتر روشهاى موجود، بامنظور شناسايى روابط ميان

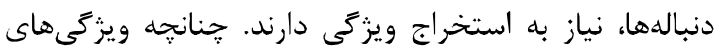

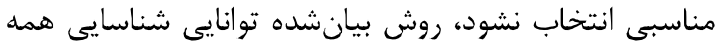

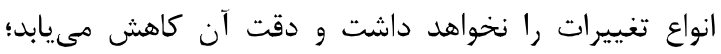
همجنين، همه روشهاى موجود بهمنظور شناسايى رانش

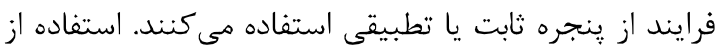

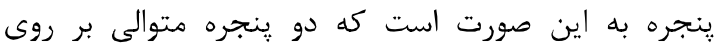

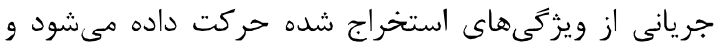

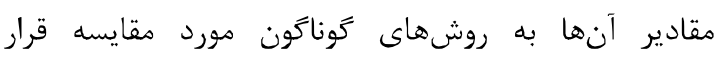
مى ميرد. اكرجه استفاده از هنجره تطبيقى، دقت ران را افزايش

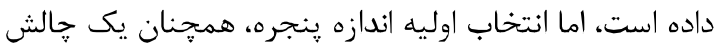
مهمم بهشمار مى آيد.

\footnotetext{
${ }^{9}$ Reccuring drift
}

${ }^{10}$ Incremental drift
از روشهاى مطرحشده براى شناسايى رانش مفهومى

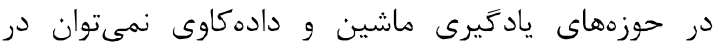
فرايندكاوى استفاده كرد، جراكه تغييرات در اين دورين دو حوزه نسبت به فرايندكاوى، ساختار بسيار سادهتى دارند. ازجمله

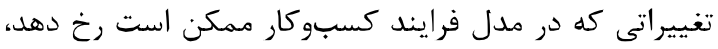

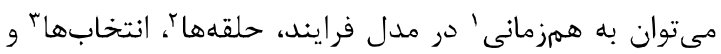
غيره اشاره كرد كه اين تغييرات، ساختار بسيار پِيجيدهترى

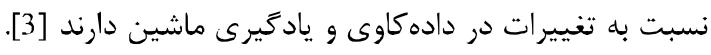
با توجه به مدتزمانى كه يك تغيير در فرايند وجود دارد،

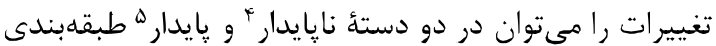
كرد. تغييرات نايايدار، تغييراتى هستند كه عمر كوتاهى دارند و فقط بر تعداد محدودى از نمونهما تأثير مى كذارند؛

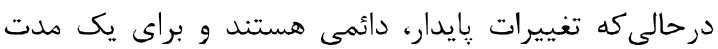

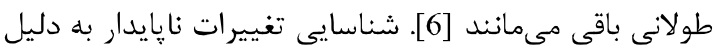

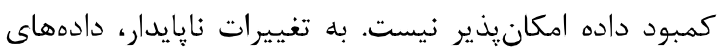

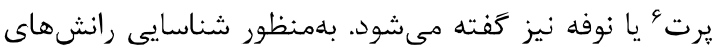

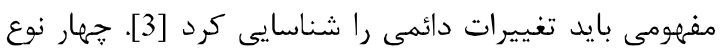

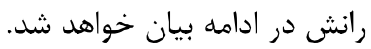

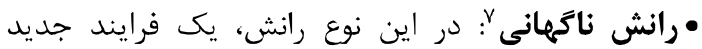

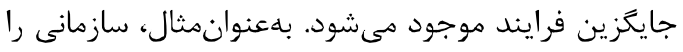
در نظر بخيريد كه بهدليل تغيير قوانين، بايد فرايند

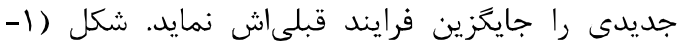

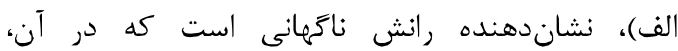

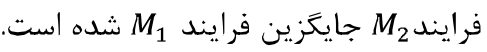
•رانش تدريجى؟ در اين نوع رانش، يك فرايند جديد

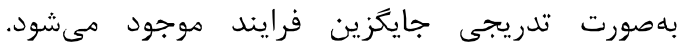

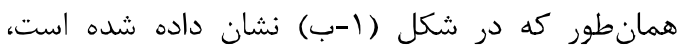
برخلاف رانش ناكمانى امكان حضور همزمان هر دو فرايند

\footnotetext{
${ }^{1}$ Concurrency

${ }^{2}$ Loops

${ }^{3}$ Choices

${ }^{4}$ Momentary

${ }_{5}^{5}$ Permanent

${ }^{6}$ Outlicr

${ }^{7}$ Sudden drift

${ }^{8}$ Gradual drift
} 
ماركوف است كه از يك ماتريس شباهت بلعنوان ورودى

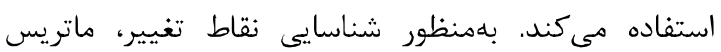

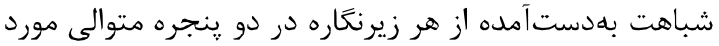

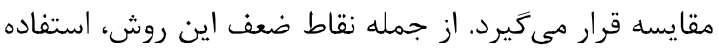
از קِنجره و نيازمندى به تنظيمات دستى است.

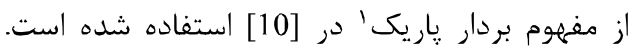

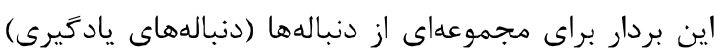

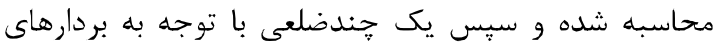

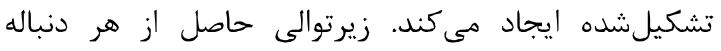

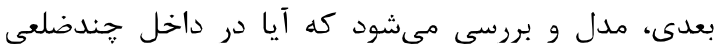

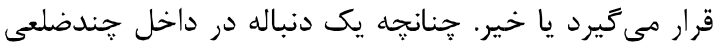
قرار بخيرد، يعنى متعلق به فرايند يكسان است؛ درحاني

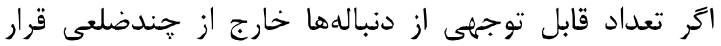

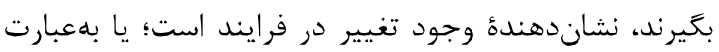
ديخر يك رانش شناسايى شده است. در اين روش امكان إندان

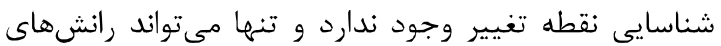

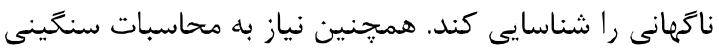
دارد.

برخلاف روش ارائهشده در [3]، الكوريتم مطرحشده

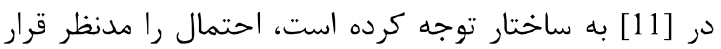
مىدهد و از اتوماتاى محدود قطعى احتمالى؟ (PDFA)

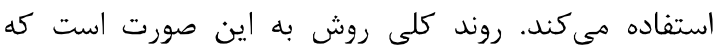

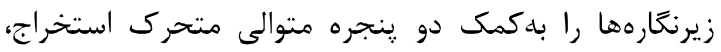

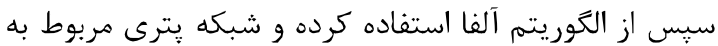

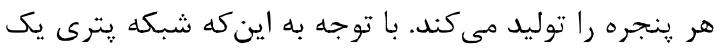

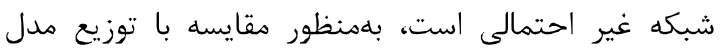

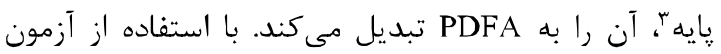

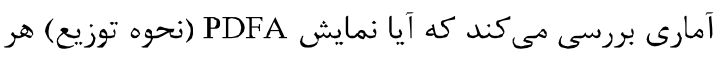
زيرنكاره با مدل بايه بهطور قابلملاحظهاى تغيير كرده است يا خير. دقت روش به مقدار داده مورد استفاده وابسته است.

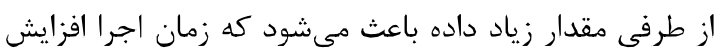

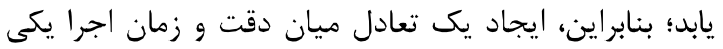

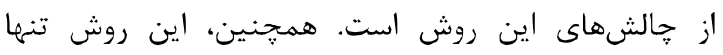
توانيى شناسايى تغييرات بزرى رائ راد دارد.

يك روش خودكار مبتنى بر مفهوم اجرا" در [12]

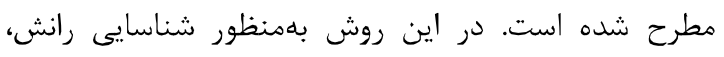
براى هر دنباله يك اجرا ساخته مى شوده؛ سيس بـ با استفاده از

1 Parikh

${ }^{2}$ Probabilistic determinestic finite automata

${ }^{3}$ Ground truth

${ }^{4}$ Run
در [3,5] روشى بلمنظور شناسايى رانشهاى ناكهانى

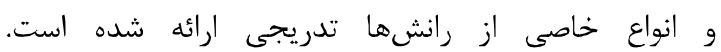

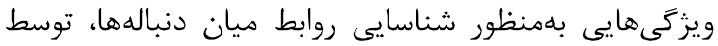
كاربر استخراج مىشود. در برخى موارد، بهمنظور انتخاب

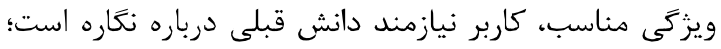

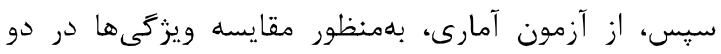
ينجره متوالى استفاده مىشود. روش ارائهشده در [3,5]

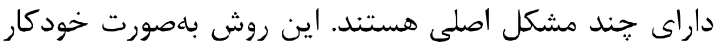

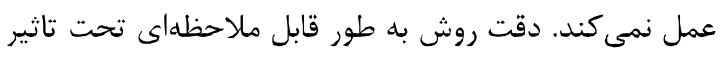

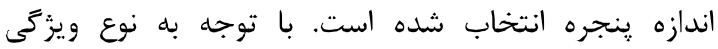
انتخابشده، ممكن است همه انواع رانشها شناسايى نشوند.

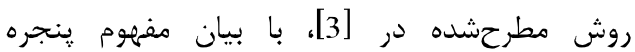
تطبيقى قصد در توسعه متد يِيشنهادى [7] را دارد. در اين

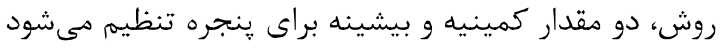

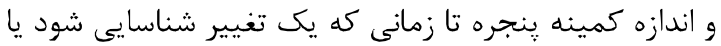

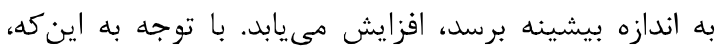

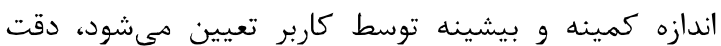

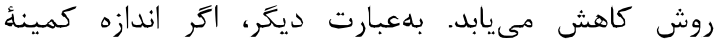

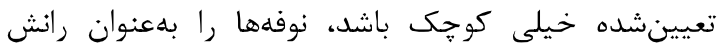

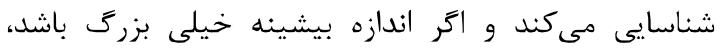

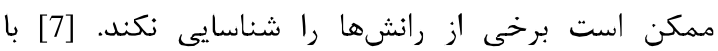

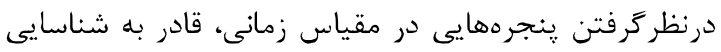
برخى از تغييرات تدريجى است. انتخاب بازه زمانى مناسب دناس

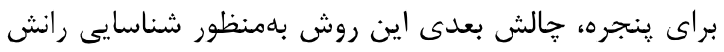

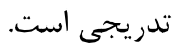
الكوريتم بيانشده در [8] با استفاده از ينجره ثابت، قادر به شناسايى رانشهاى ناكمانى، تدريجى و متناوب است.

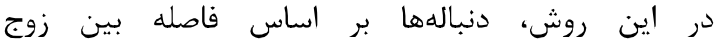

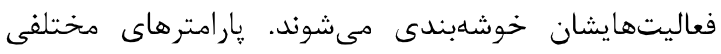

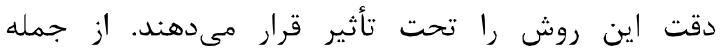

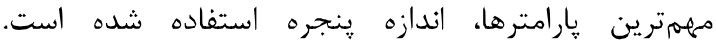

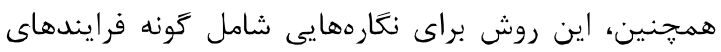

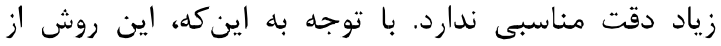

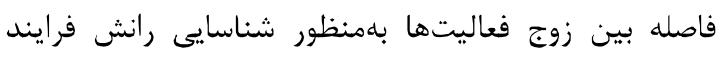
استفاده مى كند، آن دسته از رانشهايى را كه منجر به تغيير در فاصله بين فعاليتها نمى شوند شناسايى نمى كند.

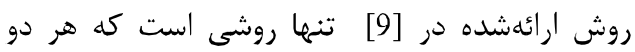

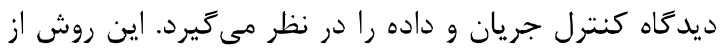

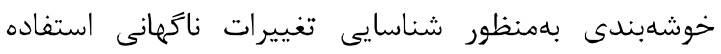
مى كند. خوشهبندى آن بر اساس الكوريتم خوشهبندى تُبن 
است؛ همجنين، از طريق محاسبه و مقايسه معيارهاى كراف،

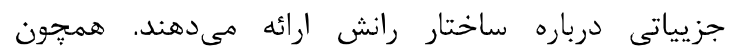
روشهاى ييشين، مشكل اصلى اين روش تعيين اندازه

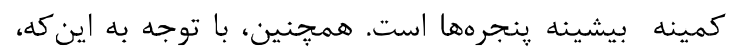

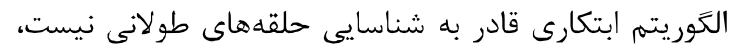

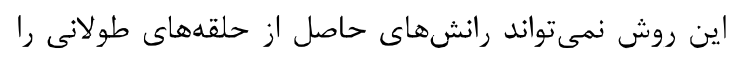

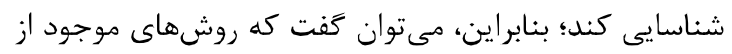

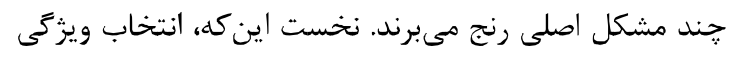

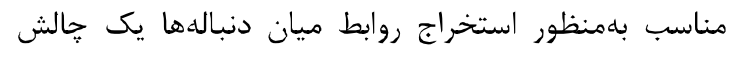

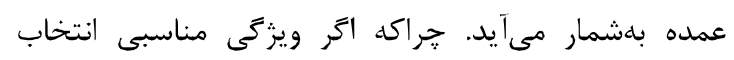

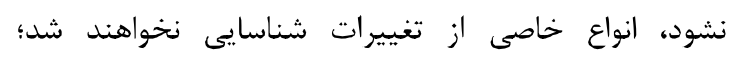

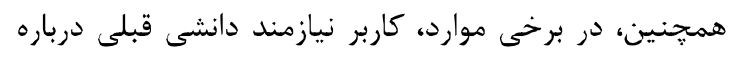

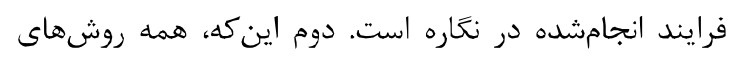

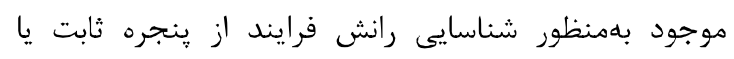

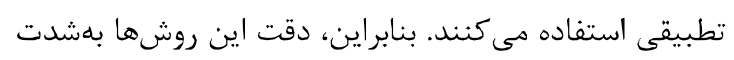

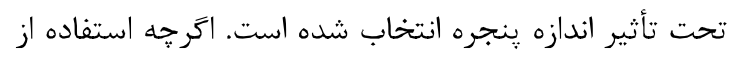

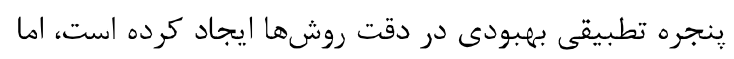

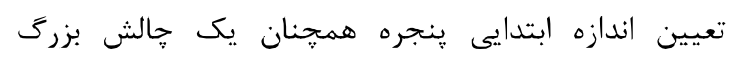
بلمشمار مى آيد.

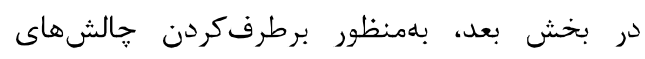

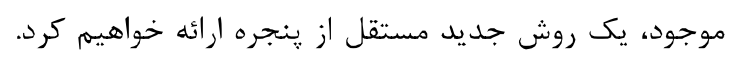

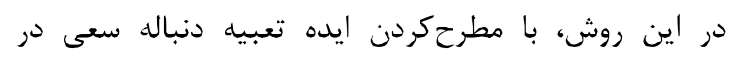

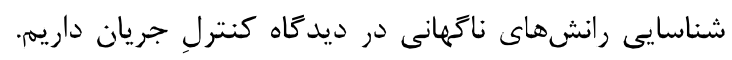

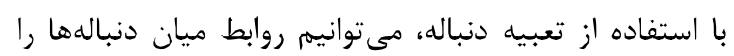

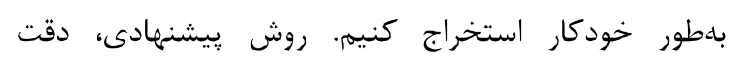
روشهاى موجود را بهبود خواهد داد.

\section{ب - ب - روش بيشنهادى}

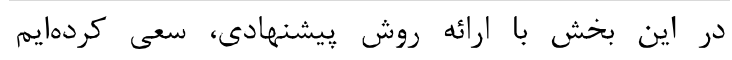

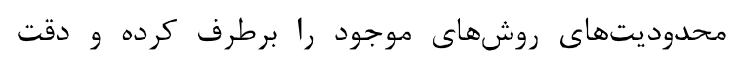

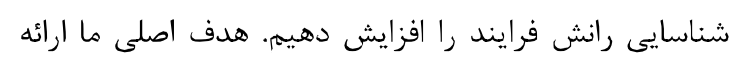

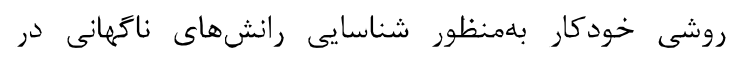
ديدكاه كنترل جريان با بهكاركيرى مفهوم تعبيه دنباله است.

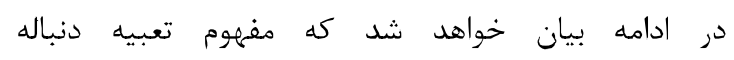

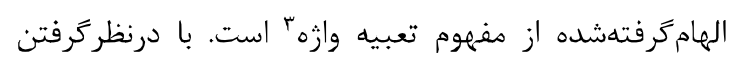

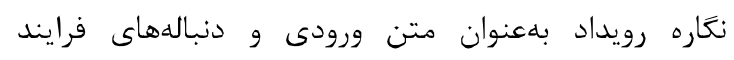

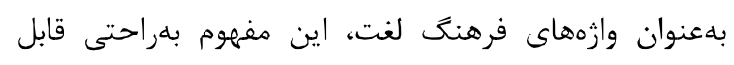

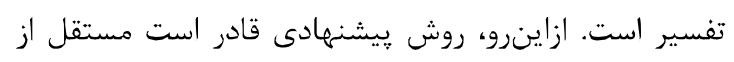

${ }^{3}$ Word cmbedding
آزمون آمارى، نحوه توزيع اجراها در دو ينجره تطبيقى

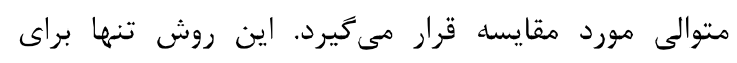

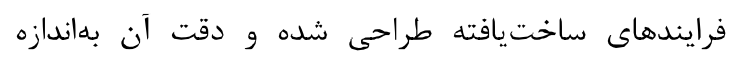
ابتدايى ينجره وابسته است. الكَوريته هطرح شده درا دابسته است [13] سعى دارد با بهبود روش موجود در [12] رانشهاى تدريجى را شناسايى كند.

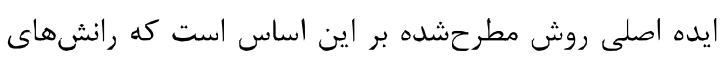

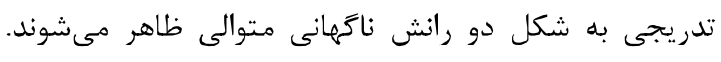

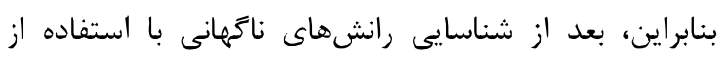

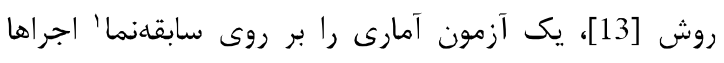

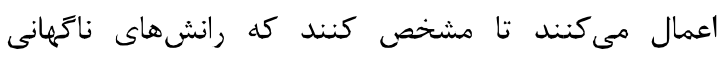

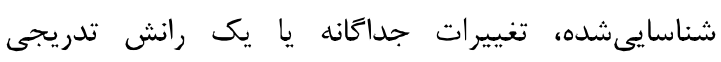

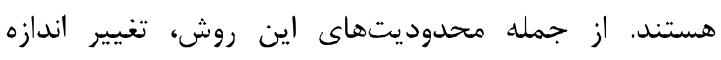

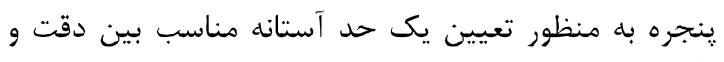

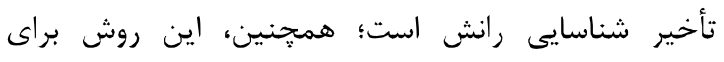

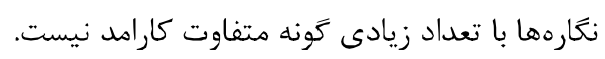

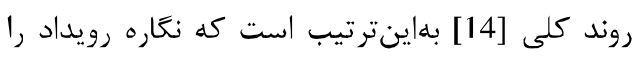

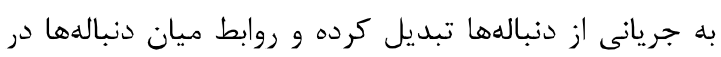

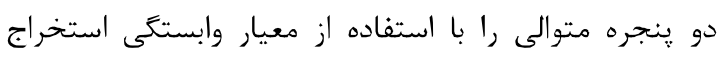

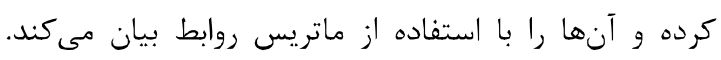

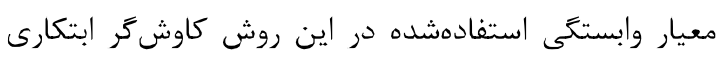

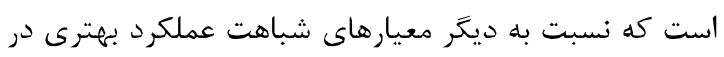

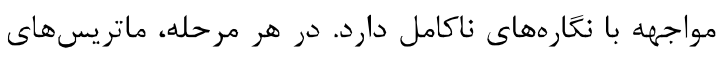

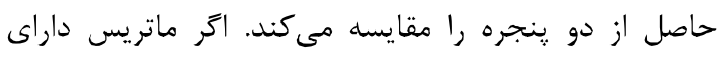

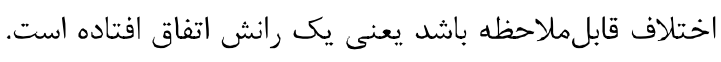

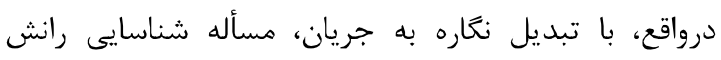

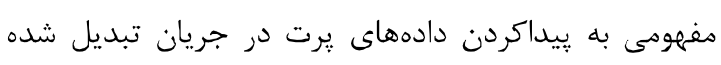

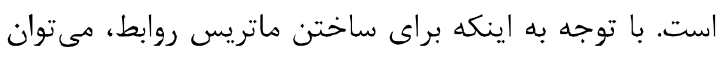

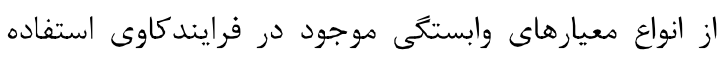

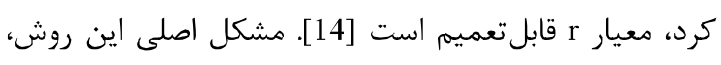

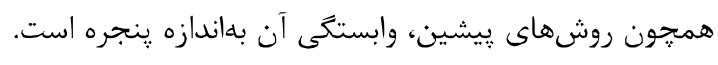

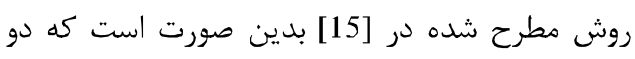

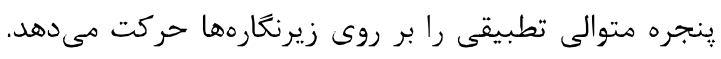

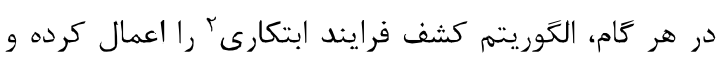

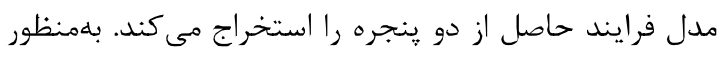

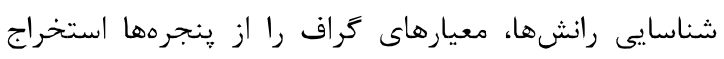

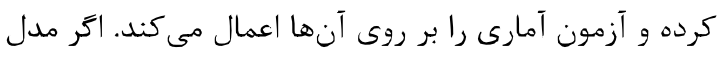

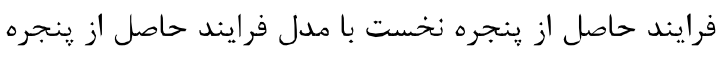

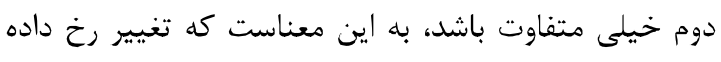

${ }^{1}$ Histogram

${ }^{2}$ Heuristic miner 
ميانگينكيرى شده و به لايه تجسمُ نكاشت داده

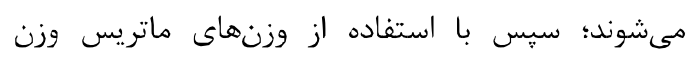

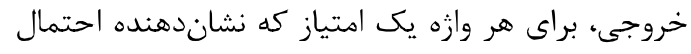

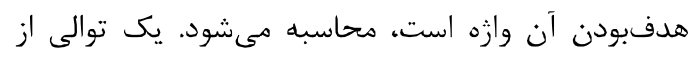
وازكان تعليم هدف

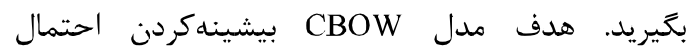
ميانكين لمَاريتم رابطه زير است [24]:

$\frac{1}{T} \sum_{t-1}^{T} \log p\left(\mathcal{W}_{t} \mid \mathcal{W}_{t-c} \cdots \mathcal{W}_{t+c}\right)$

كه احتمال (يك مدل طبقهبندى softmax $p\left(\mathcal{W}_{t} \mid \mathcal{W}_{t-c} \cdots \mathcal{W}_{t+c}\right)=\frac{\exp \left(\bar{v}^{T} v_{\mathcal{W}_{t}^{\prime}}\right)}{\sum_{w=1}^{V} \exp \left(\bar{v}^{T} v_{w}^{\prime}\right)}$

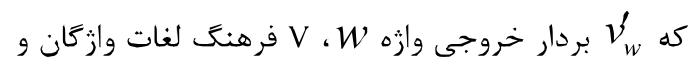
بردار ورودى ميانگين كرفتهشده از همه وازئن

$$
\bar{v}=\frac{1}{2 c} \sum_{-c \leq j \leq c . j \neq 0} v_{\mathcal{W}_{t+j}}
$$

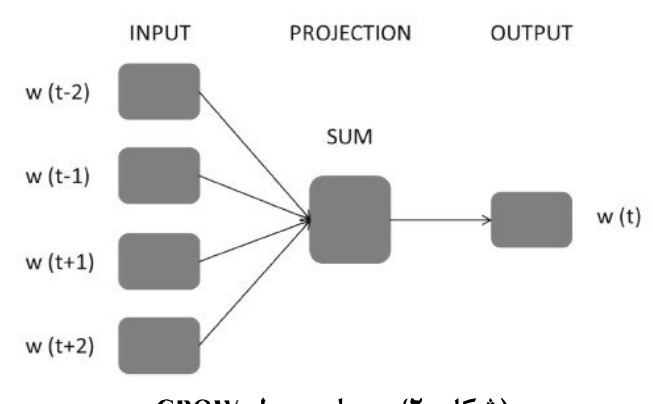

CBOW شكل - (Y): معمارى مدل)

(Figure-2): Architreture of the CBOW model

•

اين مدل برخلاف مدل CBOW سعى در بيشبينى

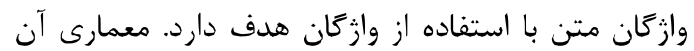

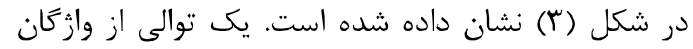
تعليم مدل Skip-gram بيشينهكردن احتمال ميانخين للخاريتم

$$
\text { رابطه زير است [24]: }
$$

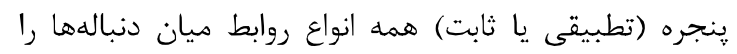

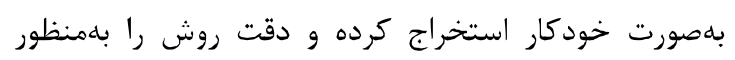
شناسايى رانش فرايند در مقايسه با روشهاى موجود افزايش دهد. در ادامه ابتدا مفاهيم اصلى در حوزه تعبيه وازهه مطرح

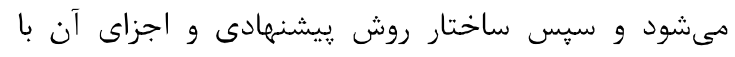
جزييات كفته خواهد شد.

ا-r- - تعبيه وازيه

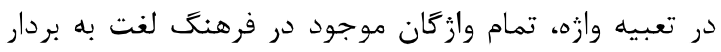

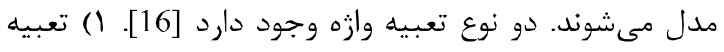

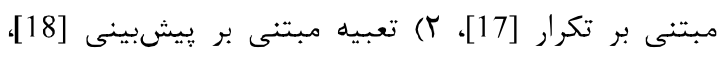

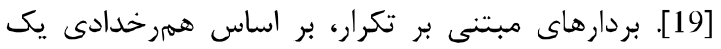

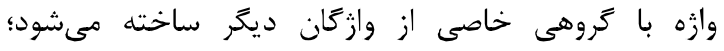

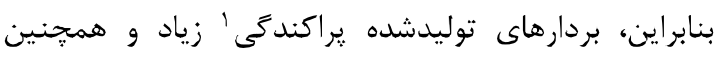

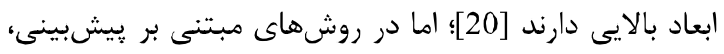

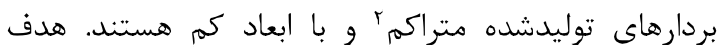

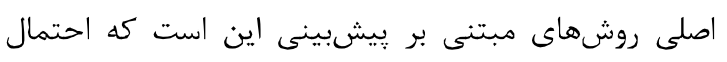

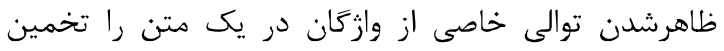

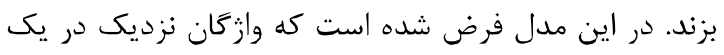

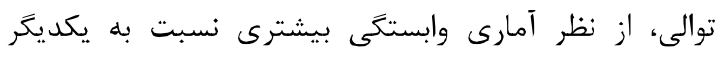

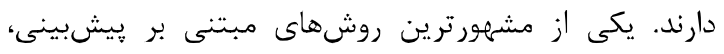

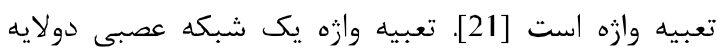

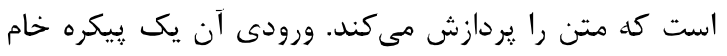

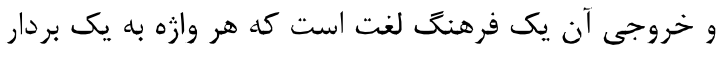

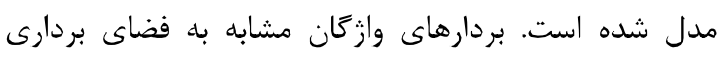

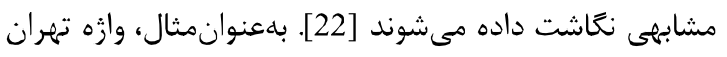

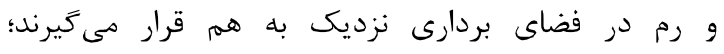

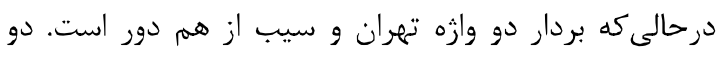

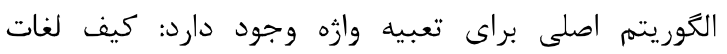

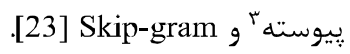

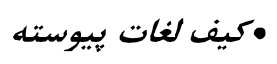

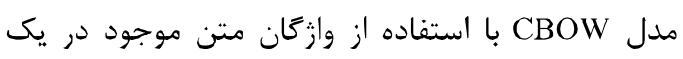

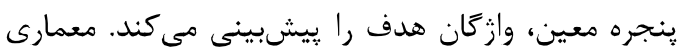

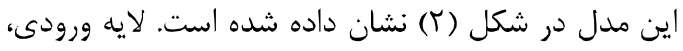

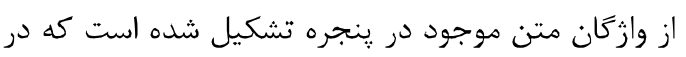

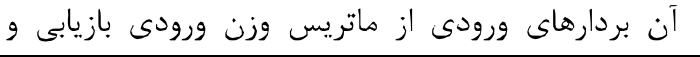

\footnotetext{
${ }^{1}$ Sparse

${ }^{2}$ Dense

${ }^{3}$ Continuous bag-of-word
} 
مطرح مى كنيم كه قادر است بهطور خودكار تمام انواع روابط ميان نبالهها را استخراج نمايد.

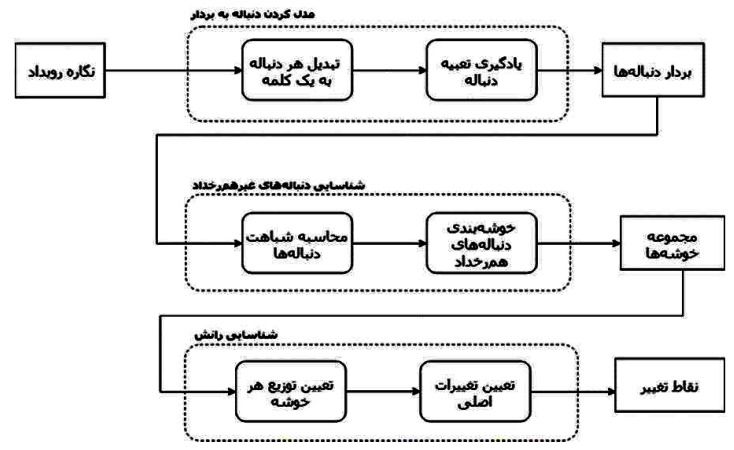
(شكل - F): روندنماى روش بيشنهادى

(Figure-4): Architrcture of the proposed approach

الف) تبديل هر دنباله به يك وازه

با درنظركرفتن فايل نكاره بهعنوان متن و دنبالههاى فرايند

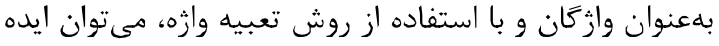
تعبيه دنباله را تفسير كرد. هدف از ايده تعبيه دنباله، توليد بردار براى دنبالههاى موجود در نغاره رويداد است؛ بهطورى كه روابط ميان برداها در فضاى بردارى نشاندهنده روابط ميان دنبالهها در نكاره باشد. برداه بهمنظور بهكارگيرى ايده تعبيه دنباله، ابتدا بايد فايل

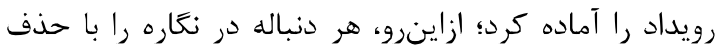
فاصله ميان فعاليتهايش به يك وازه تبديل ميك كنيهم.

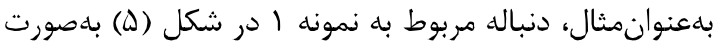
تبديل مىشود؛ سيس جريانى از دنبالهها توليد إنهات

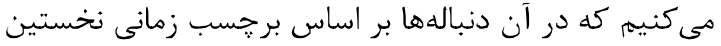
رويدادشان مرتب شدهاند.

ب) يادكيرى تعبيه دنباله تعبيه دنباله با يادگيرى' جريان توليدشده، براى هر دنباله

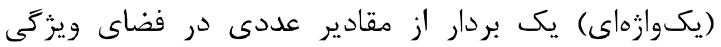

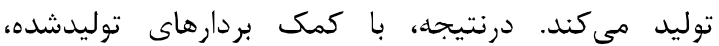

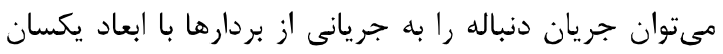

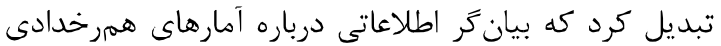

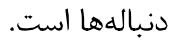
شناسايى دنبالههاى غير همر رخداد همانطور كه بِيشتر كفته شد، در رانش ناتمهانى فرايند، نمونههاى فرايند جديد جايكزين نمونههاى فرايند قبلى دئى

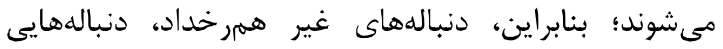
هستند كه منجر به وقوع رانش شدهاند.

${ }^{1}$ Train
$\frac{1}{T} \sum_{l=1}^{T} \sum_{-c \leq j \leq c, j \neq 0} \log p\left(w_{t-j} \mid w_{t}\right)$

كه احتمال

$$
p\left(w_{o} \mid W_{i}\right)=\frac{\exp \left(\bar{v}_{w_{o}}{ }^{T} v_{w_{i}^{\prime}}\right)}{\sum_{w=1}^{V} \exp \left(v_{w}{ }^{\prime}{ }^{T} v_{w_{i}}\right)}
$$

كه فرهنى لغت از وازّكان است.

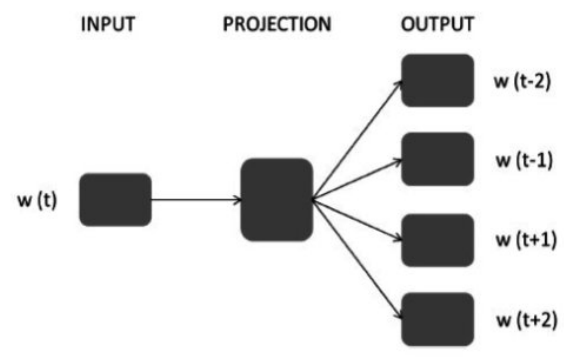

(شكل-r)

(Figure-3): Architrcture of the Skip-gram model

\section{r-r- - ساختار روش يِيشنهادى}

همانطور كه پيشتر كَته شد، روش ييشنهادى يك روش

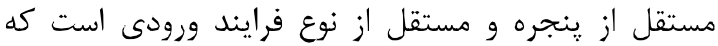
مىتواند بهصورت خودكار روابط ميان دنبالهها و رويدادها را

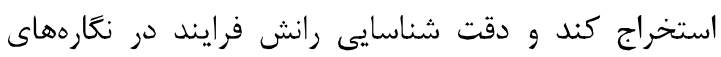

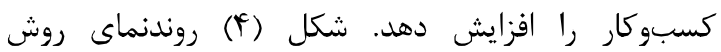
بيشنهادى را نشان مى دهد. روش بِيشنهادى از سه كام

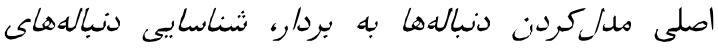

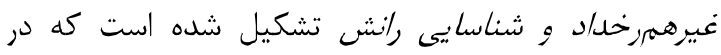

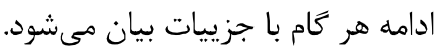

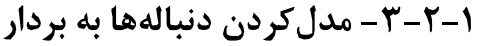

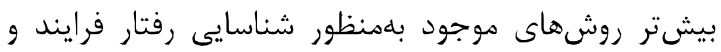

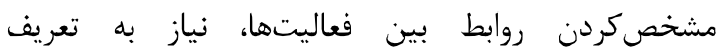

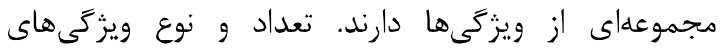

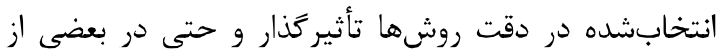

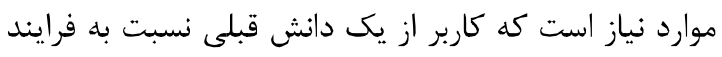

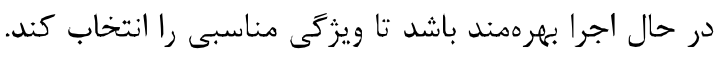

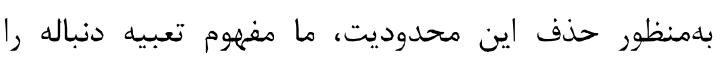


همانطور كه در شكل (9) نشان داده شده است، همه اعضاى خوشه C1 در فضاى ويزگى يكسان و در درعينحال متفاوت با اعضاى خوشه C2 قرار دارند.

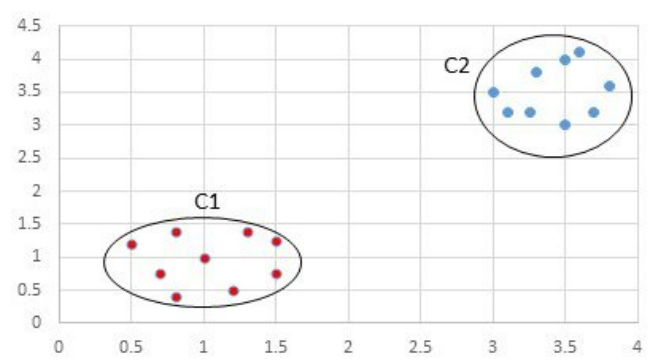

(شكل - \&): تصويرسازى دوبعدى از فضاى ويثزىى. با توجه به اين

شكل اعضاى هر خوشه در فضاى ويزّكى مشابه قرار دارند.

(Figure-6): Two-dimensional visualization of feature space. The figure illustrates that the members of each cluster are close to each other.

شناسايى رانش هدف از اين مرحله، استفاده از خوشهائ رانش توليدشده بهمنظور

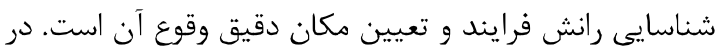

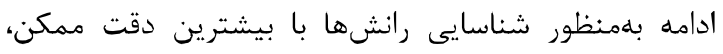
روشهاى خاصى اعمال شده است.

الف) تعيين توزيع هر خوشه

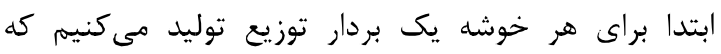

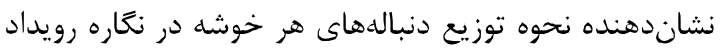

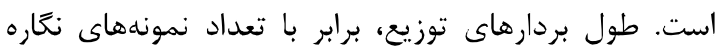

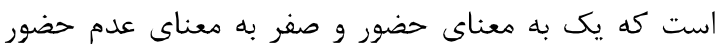

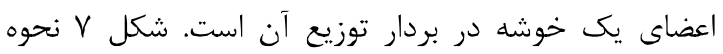

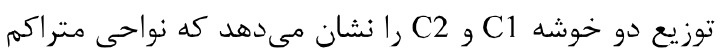

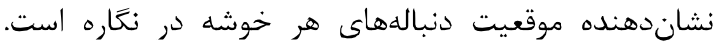

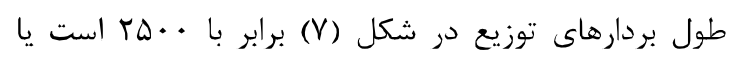

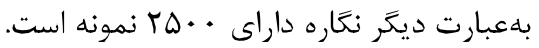
ب) تعيين تغييرات اصلى ديكر ناره بلمنظور تعيين مكانهاى يرتكرار، بردارهاى توزيع راتيني

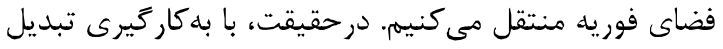

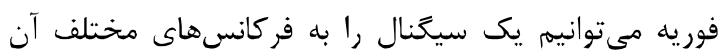

$$
\text { تجزيه كنيم [25]. }
$$

با توجه به اينكه فركانسهاى پايين نشاندهنده

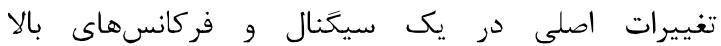

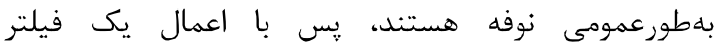

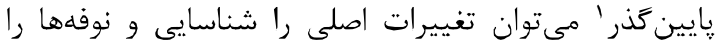

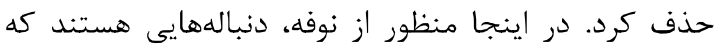
بهاشتباه در يك خوشه قراركرفتهاند.

' Low pass filter

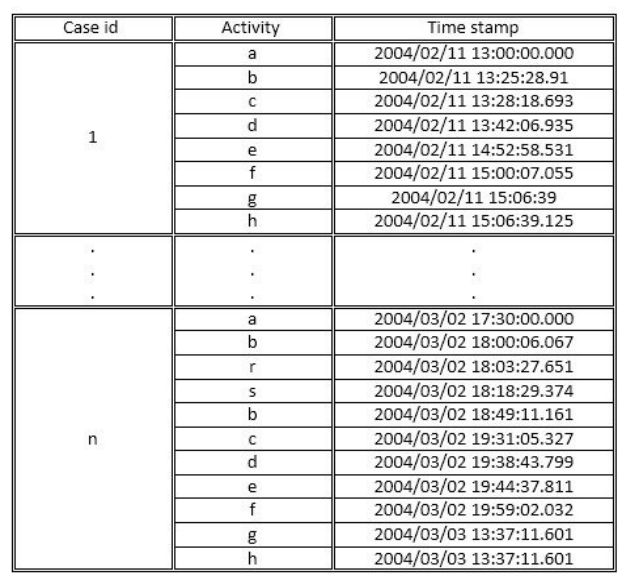

(شكل - (ه): قسمتى از يك نكاره

(Figure-5): A fragment of an event log

الف) محاسبه شباهت دنباله

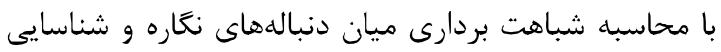
دنبالهها با كمترين شباهت يا بيشترين فاصله مي توان

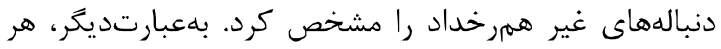

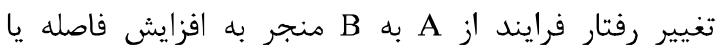

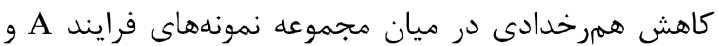

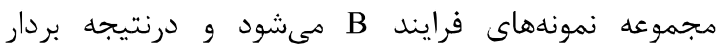
دنبالهها قبل از نقطه تغيير (وقوع رانش) با بردار دنبالهها بعد فئد

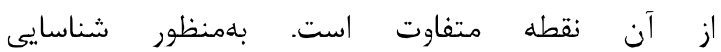
مجموعهدنبالههاى غير همرخداد، از شباهت كسينوسى ميان بردارها استفاده شده است.

ب) خوشهبندى دنبالههاى همر خداد

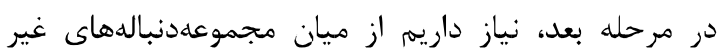

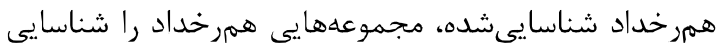

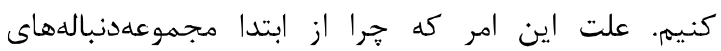

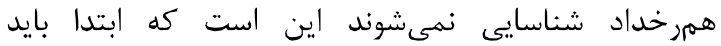

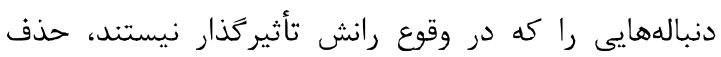

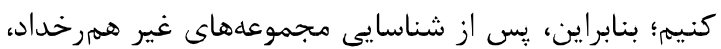

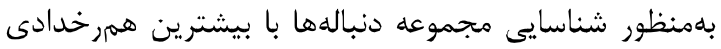

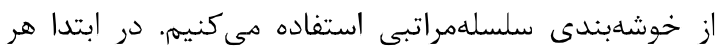
دنباله در يك خوشه قرار دارد و در هر مرحله دو خوشه با بادئ

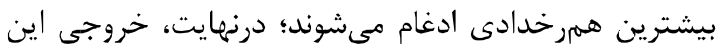

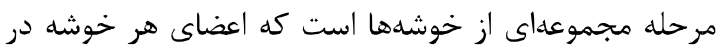
فضاى بردارى مشابه و در مقابل، در فضاى بردارى ندار نامشابه با

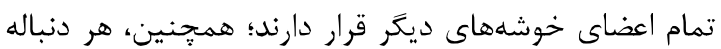

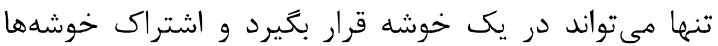

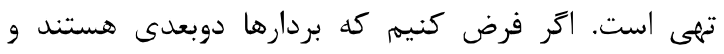
خروجى خوشهبندى سلسلهمراتبى دو خوشه C1 و C2 است، 

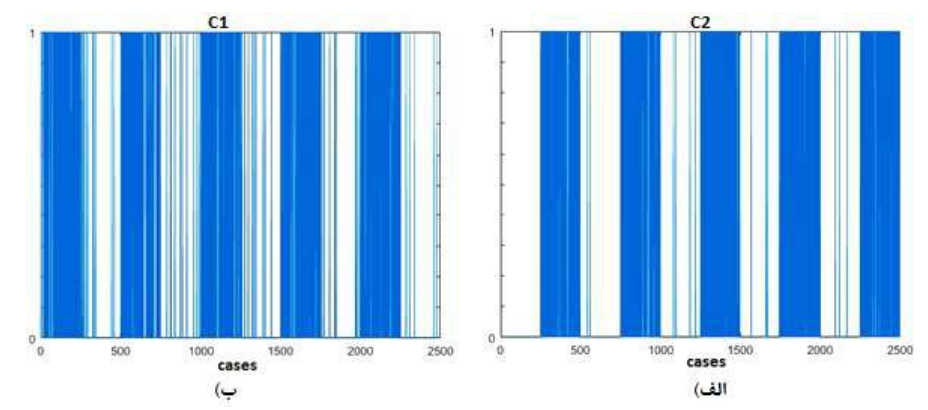

( شكل - (V): نحوه توزيع هر خوشه در نكاره

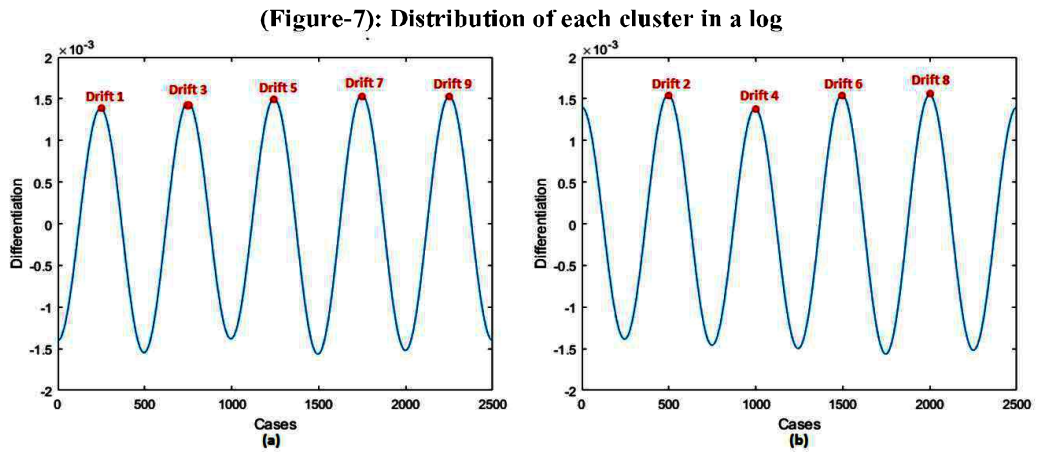

(شكل -1): الف) نرخ تغييرات در بردار توزيع خوشه C2. ب) نرخ تغييرات در بردار توزيع خوشه C1. قلهها نشاندهنده تغيير هستند.

(Figur-8): (a) Rate of changes in the distribution vector of cluster C1. (b) Rate of changes in the distribution vector of cluster $\mathrm{C} 2$. Remarkable peaks are change points.

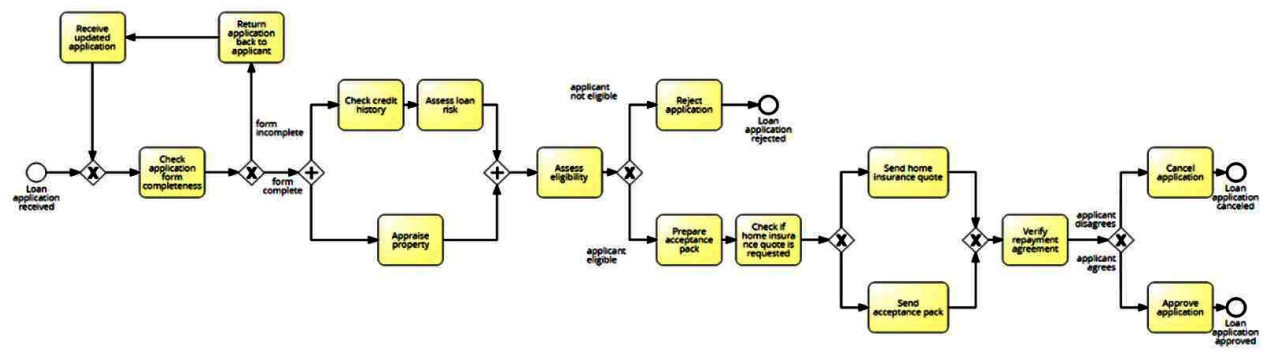

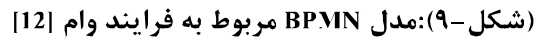

(Figure-9): Base BPMN model of loan application process

\section{F - ارزيابى نتايج}

بهمنظور ارزيابى روش زيشنهادى از مجموعهداده مطرحشده

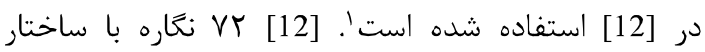

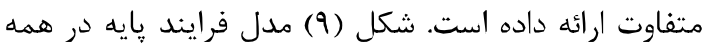
نغارهها را نشان ميدهد. اين مدل مربوط به به فرايند درخواست وام است كه شامل يانزده فعاليت، يكى رويداد

$$
\text { آغازين و سه رويداد خاتمه است. }
$$

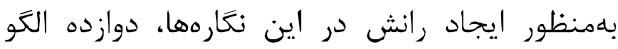

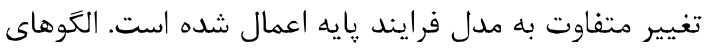
تغيير در جدول (1) نشان داده شده است. اين الخوها، بيان كننده تغييرات ممكن بر مدل فرايند كسبوركار هستند مانند، اضافه يا حذف يا حلقوى كردن يكى قطعه مدل،

\footnotetext{
${ }^{1}$ http://apromore.org/platform/tools
}

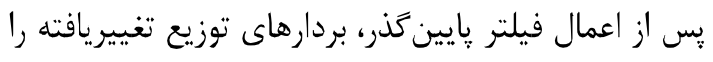

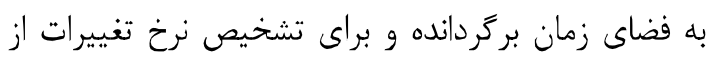

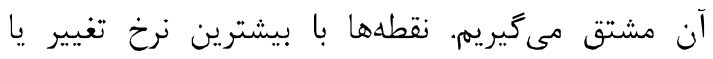

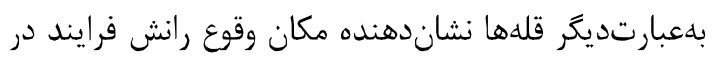

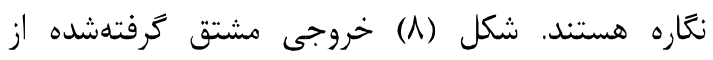

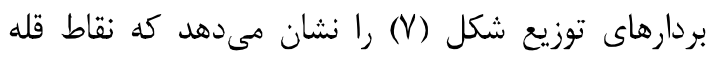

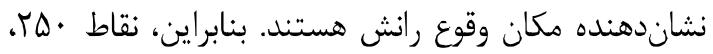

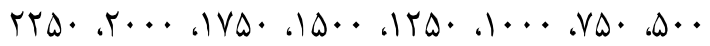
بلعنوان شاخص دنبالههايى كه در آنها رانش رخ داده است فاله

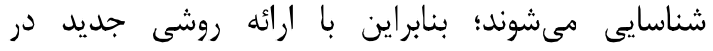

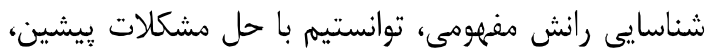
تغييرات راشناسايى كنيه. 
مواجهه با هر نغاره بلصورت جداكانه با روشهاى ديخر

هقايسه مىشود.

دو معيار امتياز F- F و متوسط تأخير بلهنودان

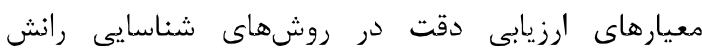

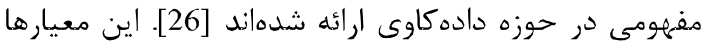

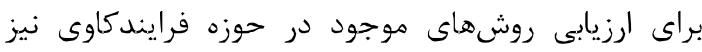

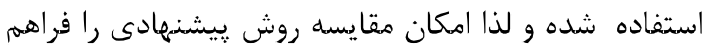

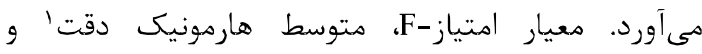

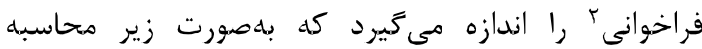

precision $=\frac{T P}{T P+F P}$

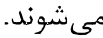

recall $=\frac{T P}{T P+F N}$

$F-$ score $=\frac{2 \times \text { precision } \times \text { recall }}{\text { precision }+ \text { recall }}$

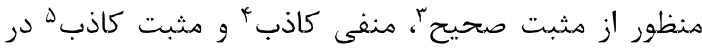

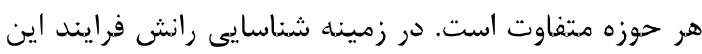
هفاهيم بهصورت زير تعريف مىشوند: •مثبت صحيح (TP): تعداد نقاطى كه بهدرستى بهعنوان رانش شناسايى شدهاند. •منفى كاذب (FN): تعداد نقاطى كله بهعنوان رانش شناسايى نشدهاند، اما در واقعيت وجود دارند.

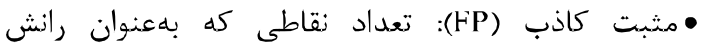
شناسايىشدهاند، اما در واقعيت وجود ندارند. متوسط تأخير هعيار ديخرى براى ارزيابى دقت است

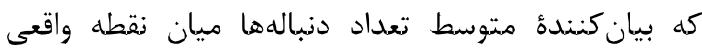
تغيير و نقطه شناسايى شده است. هر جه هيه متوسط تأخير

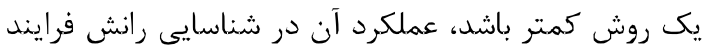
بهتر خواهد بود. در اين هزوهش از روش ارزيابى مقايسهاى استفاده

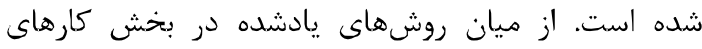
كذشته، روشهاى مطرحشده در [3, 15, 12] جهت مقايسه و ارزيابى دقت روش ييشنهمادى استفاده شدهاند. با توجه به به

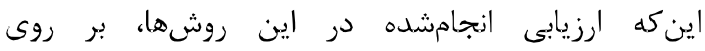

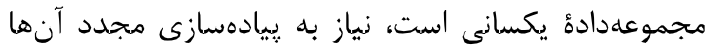

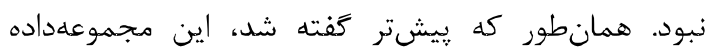
يكسانى، مجموعهداده ارائهشده در [12] است.

\footnotetext{
'Precision

${ }^{2}$ Recall

${ }^{3}$ True positive

${ }^{4}$ False negative

${ }^{5}$ False positive
}

جابهجاكردن دو قطعه مدل، يا موازىسازى دو قطعه

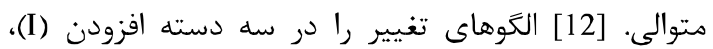

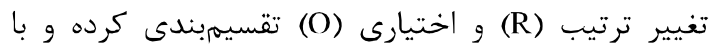

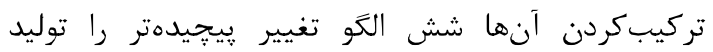

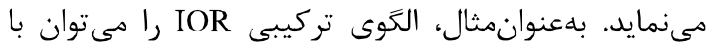
اضافهكردن يك فعاليت جديد (I)، موازى قراردادن اين فعاليت با يك فعاليت موجود (O) و درنهايت قراردادن آن آن

$$
\text { در ساختار حلقوى (R) توليد كرد. }
$$

(جدول-1): الكوهاى تغيير در ديدكاه كنترل جريان

(Table-1): Simple control-flow change patterns

\begin{tabular}{|c|c|c|}
\hline 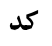 & الكو تغيير & د د ل \\
\hline $\mathrm{re}$ & حذف يا اضافهكرنن قطعه & I \\
\hline $\mathrm{cf}$ & قراردادن دو قطعه بلصورت & $\mathrm{R}$ \\
\hline $\mathrm{lp}$ & قراردادن يا خارج كردن قطعه در / از & $\mathrm{O}$ \\
\hline $\mathrm{pl}$ & قراردادن دو قطعه بهصورت & $\mathrm{R}$ \\
\hline $\mathrm{cb}$ & اضافهردن يا حذف قابليت يرش از & $\mathrm{O}$ \\
\hline $\mathrm{cm}$ & قراردادن يا خارجكردن قطعه در / از & I \\
\hline $\mathrm{cd}$ & همكامسازى دو قطعه & $\mathrm{R}$ \\
\hline $\mathrm{cp}$ & تكرار قطعه & I \\
\hline $\mathrm{pm}$ & قر ارداد يا خارجكردن قطعه در / از شاخه & I \\
\hline rp & جايكزينى قطعه & I \\
\hline sw & جابهجاكردن دو قطعه & $\mathrm{I}$ \\
\hline $\mathrm{fr}$ & تغيير تكرار شاخهها & $\mathrm{O}$ \\
\hline
\end{tabular}

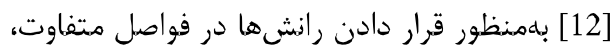

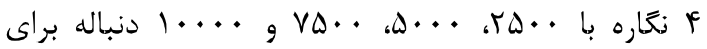
مدل فرايند يايه و براى هر يكى از هجده الكو تغيير توليد

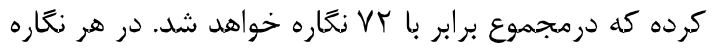
9 رانش، در هر ده درصد از اندازه آن، قرار داده شده است.

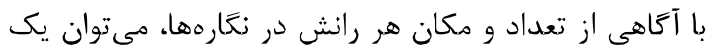
استاندارد طلايى توليد و دقت روش را با آن ارزيابى كرد. كَفتنى است كه هدف از ايجاد اين زمَارههاى ساختخى توليد مجموعهاى از دادههاى آموزش و آزمون

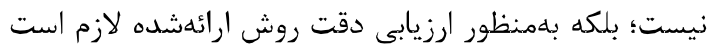
نكارههايى توليد شود كه دربردارنده انواع تغييرات ممكن

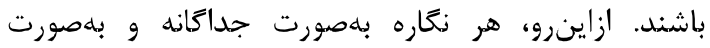

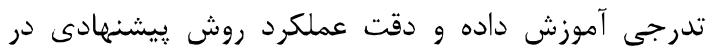


كاهش داده است. بلهور ميانكين، امتيازF-F تقريبى

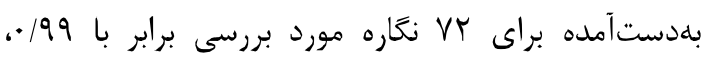

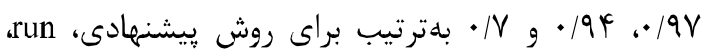
Bose g process-graph قابل توجهى نسبت به روشهاى ديكر دارد؛ همجنين، متوسط تأخير تقريبى بهدستآمده براى VY نكاره مورد

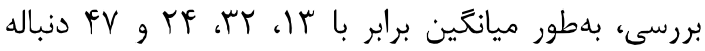

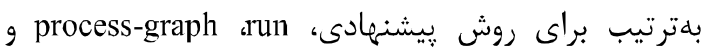
Bose شناسايىشده توسط روش ييشنهادى حدود سيزده دنباله با مكان واقعى رانش فاصله دارد كه سه روش ديكر را بهبود

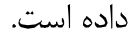

در آزمايش بعدى، روش ي بيشنهادى را بر روى نكاره

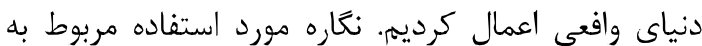

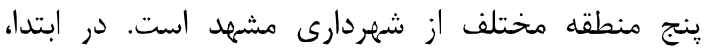
بلمنظور بالابردن كيفيت تحليل، ويشيشدازشهايى براى

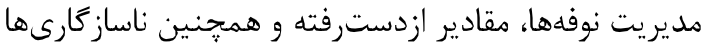
بر روى پإيخاه داده انجام شد.
معيارهاى امتياز -F و متوسط تأخير براى هر يك از الكوهاى تغيير محاسبه شده است. نتايج دقيق اين معيارها براى هر الكو در روش ويشنهادى بلددست آمده و بلهمراه نتايج روشهاى ديكر در جدول (r) نشان داده شده است. نتايج اين جدول به ازاى هر الكوى تغيير بر روى جهار نكاره

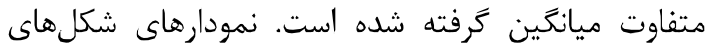

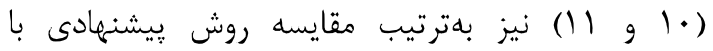

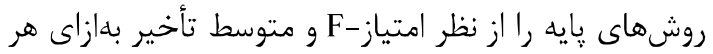

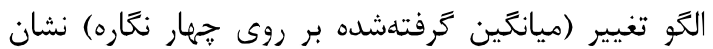
مىدهند. همانطور كه در نمودار شكل (•l) مشاهده مى كنيد، روش بيشنهادى به امتيازF- برابر يك براى همة

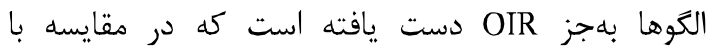

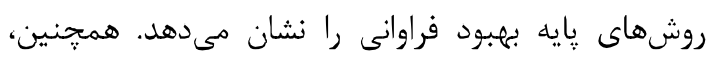

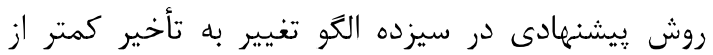
بيست دنباله، در سه الكو تغيير به تأخير كمتر از سى سئردير دنباله

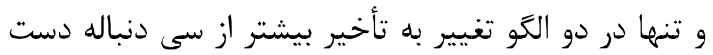

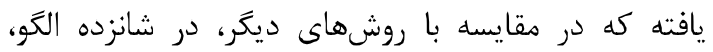

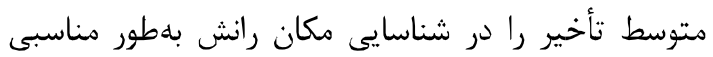

(جدول - Y): مقادير دقيق روش بيشنهادى از دو ديدكاه امتياز -Fose و متوسط تأخير در مقايسه با روشهاى Process-graph،run.

(Table-2): Comparison of average $F$-score and mean delay values

\begin{tabular}{|c|c|c|c|c|c|c|c|c|}
\hline \multirow[b]{2}{*}{ الكو تغيير } & \multicolumn{2}{|c|}{ trace 2 vec } & \multicolumn{2}{|c|}{$\operatorname{run}[\mid r]$} & \multicolumn{2}{|c|}{ process graph [1ه] } & \multicolumn{2}{|c|}{ Bose[r] } \\
\hline & F-متياز F & تأخير & F-متياز & تأخير & Fتياز Fت Fت & متوسط & Fتياز Fت & تأخير \\
\hline $\mathrm{Re}$ & 1 & 21.83 & 1 & 44.03 & 0.9036 & 33.02 & 1 & 17 \\
\hline Cf & 1 & 5.08 & 0.9824 & 21 & 0.9853 & 34.62 & 0.8950 & 36 \\
\hline Lp & 1 & 21.69 & 1 & 40.29 & 0.7618 & 48.03 & 0.6484 & 41 \\
\hline Pl & 1 & 13.8 & 1 & 35.74 & 0.9575 & 26.33 & 1 & 20 \\
\hline $\mathrm{Cb}$ & 1 & 9.1 & 0.9387 & 58.55 & 0.9722 & 18.94 & 0 & 0 \\
\hline $\mathrm{Cm}$ & 1 & 8.52 & 1 & 39.85 & 0.9722 & 19.24 & 0 & 0 \\
\hline Cp & 1 & 4.58 & 1 & 19.66 & 0.9853 & 17.59 & 0.6394 & 36 \\
\hline Cd & 1 & 46.44 & 0.8799 & 34.62 & 0.9546 & 28.62 & 1 & 20 \\
\hline Pm & 1 & 11.97 & 1 & 12.88 & 0.9869 & 24.78 & 0.7804 & 69 \\
\hline $\mathbf{R p}$ & 1 & 4.86 & 0.9666 & 19.18 & 0.9722 & 12.67 & 0.75 & 40 \\
\hline Sw & 1 & 6.02 & 1 & 21.67 & 1 & 29.61 & 0.7804 & 39 \\
\hline $\mathbf{F r}$ & 1 & 20.5 & 0.7569 & 49.92 & 0.9853 & 19.92 & 0.4420 & 165 \\
\hline IOR & 1 & 36.66 & 1 & 19.11 & 0.9606 & 13 & 0.7804 & 38 \\
\hline IRO & 1 & 6.8 & 1 & 43.96 & 0.9487 & 27.22 & 0.5611 & 82 \\
\hline OIR & 0.9967 & 12.11 & 0.9803 & 47.89 & 0.7331 & 28.06 & 1 & 20 \\
\hline ORI & 1 & 11.38 & 1 & 14.51 & 0.9869 & 14.25 & 0.7804 & 38 \\
\hline RIO & 1 & 9.08 & 0.9824 & 23.81 & 0.9722 & 20.77 & 0.5611 & 60 \\
\hline ROI & 1 & 7.66 & 1 & 22.51 & 1 & 7.31 & 1 & 20 \\
\hline ميانغين & 0.9998 & 12.15 & 0.9715 & 31.62 & 0.9466 & 23.56 & 0.7010 & 46.31 \\
\hline
\end{tabular}


atrace2vec $\square$ run $\mathbf{\Delta}$ process-graph Bose

1.2

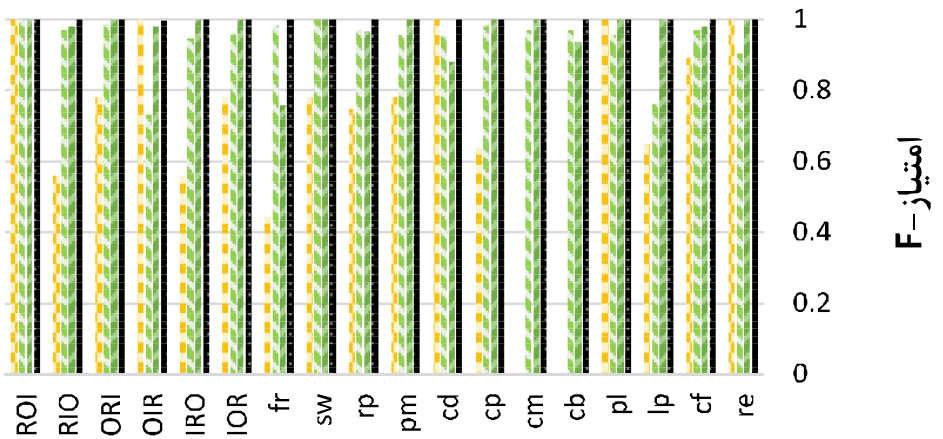

$$
\text { الكوى تغيير }
$$

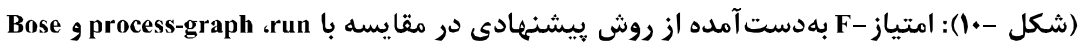

(Figure-10): Comparison of F-score values per change pattern

- trace2vec run process-graph Bose

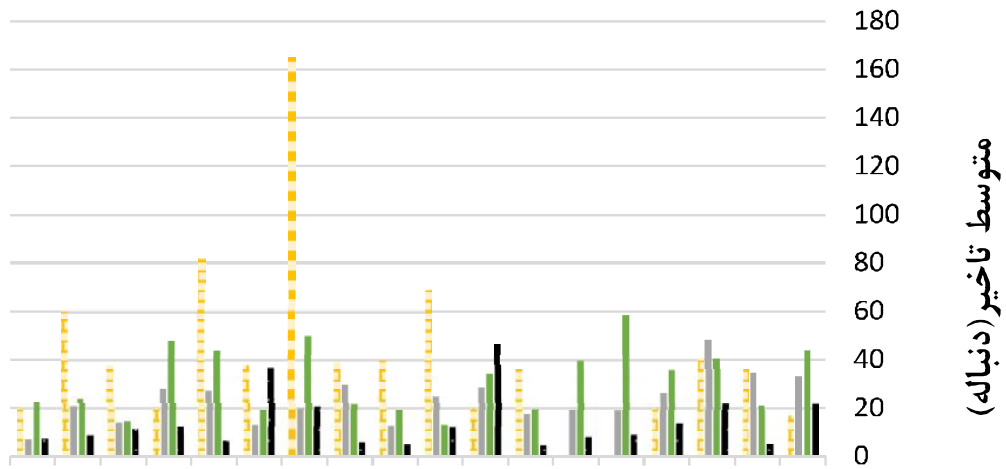

ROIRIOORIOIRIROIOR fr sw $\mathrm{rp}$ pm cd $\mathrm{cp} \mathrm{cm}$ cb pl lp cf re

$$
\text { الكوى تغيير }
$$

Bose ،process-graph ،run شكل -11): متوسط تأخير بهدست آمده از روش بيشنهادى در مقايسه با (Figure-11): Comparison of mean delay values per change pattern
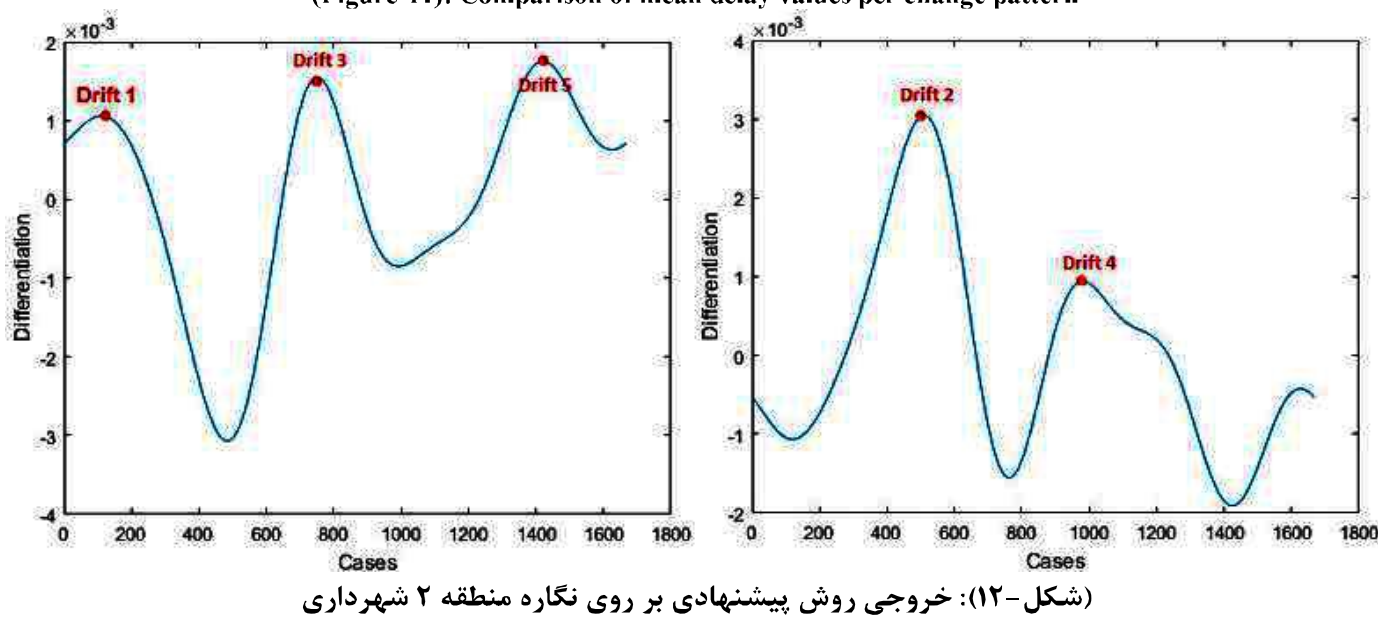

(Figure-12): Plots of the output results after applying the trace2vec approach to M2 
ييشنهادى بر روى نكاره واقعى نيز نشان داده شده است.

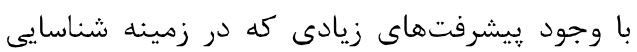

رانش فرايند انجام شده است، اما هنوز موضوعات باز براى

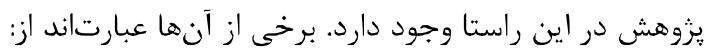
•ارائه روشى بهمنظور شناسايى رانشها در دينى ريداه داده و منبع: هيج يك از روشهاى دوجود توانايى

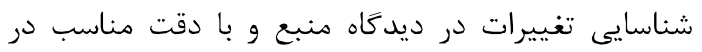

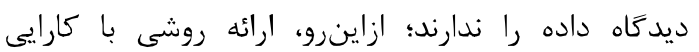

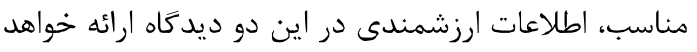
كرد.

•ارائه روشى بهمنظور شناسايى رانشهاى تدريجى با

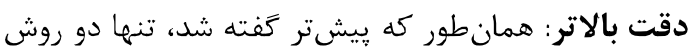
مطرحشده در [7] و [13] توانايى شناسايى رانشهاى تدريجى را دارند. با اين حال، نتايج ارائهشده توسط آنهائ آنها

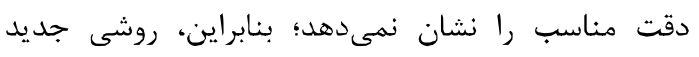

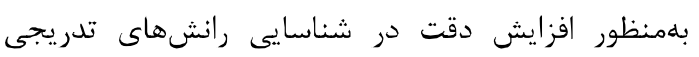
حائز اهميت است.

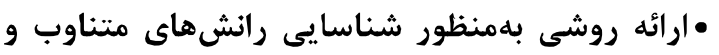
افزايشى: شناسايى رانشهاى متناوب و افزايشى با دقت مناسب، اطلاعات ارزشمندى درباره عوامل تأثيركذار بر

$$
\text { فرايند سازمان ارائه ميدهدات }
$$

\section{6- References}

\section{9- مراجع}

[1] W. Van Der Aalst, A. Adriansyah, A. K. A. De Medeiros, F. Arcieri, T. Baier, T. Blickle, et al., "Process mining manifesto", in International Conference on Business Process Management, vol. 37 No.3, pp. 169-194, 2011.

[2] M. U. Lavanya and M. S. K. Talluri, "Dealing With Concept Drifts In Process Mining Using Event Logs", International Journal Of Engineering And Computer Science, vol. 4, pp. 13433-13437, 2015.

[3] R. J. C. Bose, W. M. Van Der Aalst, I. Žliobaité, and M. Pechenizkiy, "Dealing with concept drifts in process mining", IEEE transactions on neural networks and learning systems, vol. 25 No.1, pp. 154-171, 2014.

[4] J. C. Schlimmer and R. H. Granger, "Beyond Incremental Processing: Tracking Concept Drift", the Association for the Advancement of Artificial Intelligence, pp. 502-507, 1986.

[5] R. J. C. Bose, W. M. van der Aalst, I. Žliobaitè, and M. Pechenizkiy, "Handling concept drift in process mining", 23rd International Conference on Advanced Information Systems
بهدليل محدوديت فضا، تنها نتايج حاصل بر روى يك

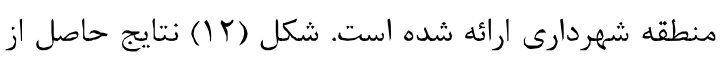

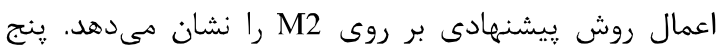

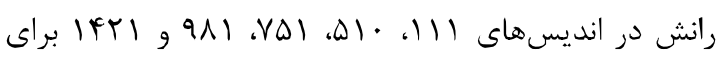
شهردارى منطقه r شناسايى شده، اين درحالى است كه با

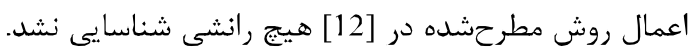

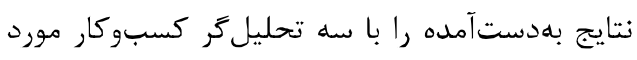
ارزيابى قرار داديم. نتيجه ارزيابعها حاكى از عملكرد صحيح روش ييشنهادى بود. تحليل رانشها را وجود دو تغيير در فرايند سازمان اعلام كردند:

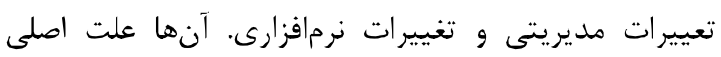
تغييرات نرمافزارى را بهيبود كارايى فرايند كسبوكير كار بيان كردند كه منجر به كاهش تعداد نمونهما در فرايند مى شيود.

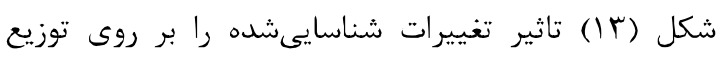
تعداد نمونهها در طى زمان نشان مىدهد. همانطوركه در

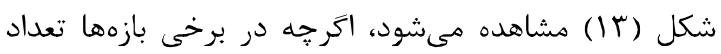
نمونهها افزايش يافته، اما درنهايت تعداد نمونههاى متمايز در اين منطقه از شهردارى كاهش يافته كه اين دليلى بر بهبود يافئه كارايى فرايند است.

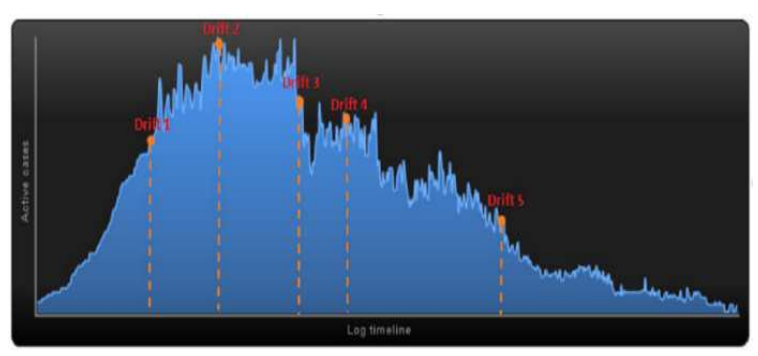

(شكل - بr): موقعيت رانشهاى شناسايىشده بر روى نمودار

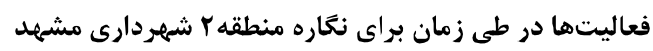

(Figure-13): The position of the drifts detected by our approach shown in a plot of active cases vs $\log$ timeline for $\mathbf{M 2}$

\section{ه- نتيجه}

در اين مقاله، سعى شد با ارائه مفهومى جديد دقت روشهاى ييشين در شناسايى رانش فرايند را افزايش دهيه. با بيان

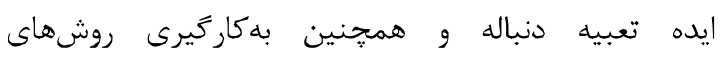
خوشهبندى و تبديل فوريه روشى را ارائه كرديم كه همه

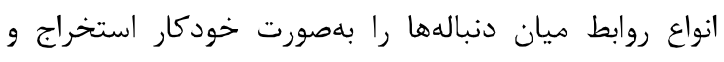
بدون استفاده از ينجره، رانشهاى ناگُهانى را شناسايى كند.

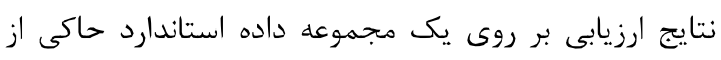

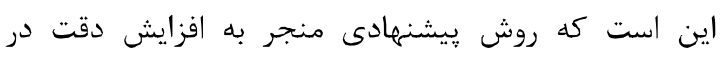
شناسايى رانش فرايند شده است؛ همجنين، عملكرد روش 
[16] M. Baroni, G. Dinu, and G. Kruszewski, "Don't count, predict! A systematic comparison of context-counting vs. context-predicting semantic vectors", ACL (1), pp. 238-247, 2014.

[17] S. Deerwester, S. T. Dumais, G. W. Furnas, T. K. Landauer, and R. Harshman, "Indexing by latent semantic analysis," Journal of the American society for information science, vol.41, p. 391, 1990.

[18] A. Mandelbaum and A. Shalev, "Word Embeddings and Their Use In Sentence Classification Tasks," arXiv preprint arXiv:1610.08229, 2016.

[19] T. Mikolov, W.-t. Yih, and G. Zweig, "Linguistic regularities in continuous space word representations", HLT-NAACL, Atalanta, USA, pp.746-751, 2013.

[20] Q. V. Le and T. Mikolov, "Distributed Representations of Sentences and Documents", ICML, Beijing, China, pp. 1188-1196, 2014.

[21] T. Mikolov, K. Chen, G. Corrado, and J. Dean, "Efficient estimation of word representations in vector space", arXiv preprint arXiv:1301.3781, 2013.

[22] T. Mikolov, I. Sutskever, K. Chen, G. S. Corrado, and J. Dean, "Distributed representations of words and phrases and their compositionality", the 27th Conference on Neural Information Processing Systems(NIPS), Nevada, United States, pp. 3111-3119, 2013.

[23] X. Rong, "word2vec parameter learning explained", arXiv preprint arXiv:1411.273, 2014.

[24] P. Ristoski and H. Paulheim, "Rdf2vec: Rdf graph embeddings for data mining", 15th International Semantic Web Conference(ISWC), Kobe, Japan, pp. 498-514, 2016.

[25] M. Rahman, "Applications of Fourier transforms to generalized functions", WIT Press, 2011.

[26] S.-S. Ho, "A martingale framework for concept change detection in time-varying data streams", the 22nd international conference on Machine learning, Germany, ACM, pp. 321-327, 2005.

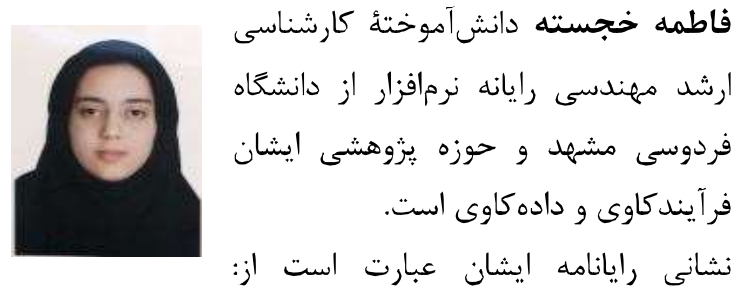

fatemeh.khojasteh@mail.um.ac.ir
Engineering(CAiSE), London, UK, Springer, pp. 391-405, 2011.

[6] H. Schonenberg, R. Mans, N. Russell, N. Mulyar, and W. van der Aalst, "Process flexibility: $A$ survey of contemporary approaches", 4th International Workshop on Advances in Enterprise Engineering I, Springer, pp. 16-30, 2008.

[7] J. Martjushev, R. J. C. Bose, and W. M. van der Aalst, "Change Point Detection and Dealing with Gradual and Multi-order Dynamics in Process Mining", 14th International Conference on Business Informatics Research, Tartu, Estonia, Springer, pp. 161-178, 2015.

[8] R. Accorsi and T. Stocker, "Discovering workflow changes with time-based trace clustering" , International Symposium on DataDriven Process Discovery and Analysis, Italy, Springer, pp. 154-168, 2011.

[9] B. Hompes, J. Buijs, W. van der Aalst, P. Dixit, and J. Buurman, 2015, "Detecting Change in Processes Using Comparative Trace Clustering", the 5th International Symposium on Data-driven Process Discovery and Analysis (SIMPDA), Vienna, Austria , pp. 95-108.

[10] J. Carmona and R. Gavalda, "Online techniques for dealing with concept drift in process mining", 11th International Symposium on Intelligent Data Analysis, Finland, Springer, pp.90-102, 2012.

[11] P. Weber, B. Bordbar, and P. Tiño, "Real-Time Detection of Process Change using Process Mining", ICCSW, United Kingdom, 2011.

[12] A. Maaradji, M. Dumas, M. La Rosa, and A. Ostovar, "Fast and accurate business process drift detection", the 13th International Conference on Business Process Management, Austria, Springer, pp. 406-422, 2015.

[13] A. Maaradji, M. Dumas, M. L. Rosa, and A. Ostovar, "Detecting Sudden and Gradual Drifts in Business Processes from Execution Traces", IEEE Trans. Knowl. Data Eng., vol. 29, pp. 2140-2154, 2017.

[14] T. Li, T. He, Z. Wang, Y. Zhang, and D. Chu, "Unraveling Process Evolution by Handling Concept Drifts in Process Mining", in Services Computing (SCC), IEEE International Conference on, pp. 442-449, 2017.

[15] A. Seeliger, T. Nolle, and M. Mühlhäuser, "Detecting Concept Drift in Processes using Graph Metrics on Process Graphs", Proceedings of the 9th Conference on Subject-oriented Business Process Management, 2017. 


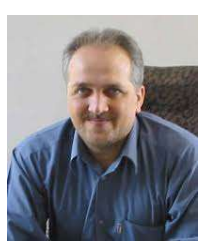

$$
\begin{aligned}
& \text { محسن كاهانى استادتمام كَروه رايانه و }
\end{aligned}
$$

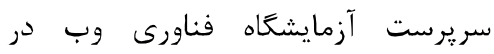

$$
\begin{aligned}
& \text { دانشگاه فردوسى مشهد است. حوزهماى }
\end{aligned}
$$

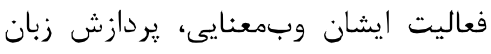

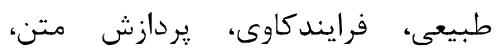

$$
\begin{aligned}
& \text { تحليل نظرات، دادههاى حجيم است. } \\
& \text { نشانى رايانامه ايشان عبارت است ازئ }
\end{aligned}
$$

kahani@um.ac.ir

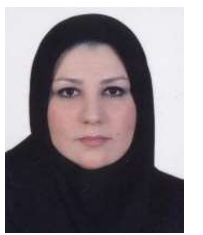

بهشيد بجكمال استاديار دانشكاه فردوسى

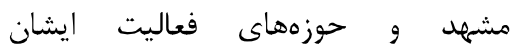
دادهكاوى، فرايندكاوى و دادههاى ييوندى است. - است behkamal@um.ac.ir

$$
\text { نشانى رايانامه ايشان عبارت است از: }
$$

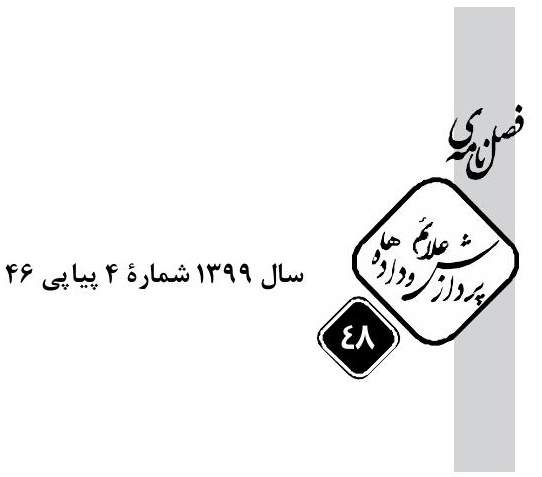

